University of St. Thomas, Minnesota

UST Research Online

Finance Faculty Publications

Finance

4-2016

\title{
CEOs religious affiliation and managerial conservatism
}

Mufaddal Baxamusa

University of St. Thomas, Minnesota, mufaddalb@stthomas.edu

Abu M. Jalal

Suffolk University, ajalal@suffolk.edu

Follow this and additional works at: https://ir.stthomas.edu/ocbfincpub

This Article is brought to you for free and open access by the Finance at UST Research Online. It has been accepted for inclusion in Finance Faculty Publications by an authorized administrator of UST Research Online. For more information, please contact asle4660@stthomas.edu. 


\section{CEO'S Religious Affiliation and Managerial Conservatism}

We investigate whether manager's religious affiliations affect corporate decisions. We hand collect data on the religious affiliations of CEOs and find that firms with Catholic CEOs have less leverage, issue debt less often, increase business and geographic diversification, and invest less than firms with Protestant CEOs. We also find that the decisions of Catholic CEOs are associated with lower firm value. These corporate actions are also reflected in the CEOs' personal decisions, such as owning fewer company stocks and playing less risky sports.

Mufaddal Baxamusa is an Associate Professor in the Department of Finance, Opus College of Business, University of St. Thomas, St. Paul, MN 55105.

Abu Jalal is an Associate Professor in the Department of Finance, Sawyer Business School, Suffolk University, Boston, MA 02108.

We are grateful to the editor of this journal, Raghavendra Rau, and an anonymous referee. Both were extremely generous with their time and helped to immensely improve the study. We thank Rajesh Aggarwal, Anand Jha, John Thornton, and seminar participants at the University of St Thomas, Suffolk University, Financial Management Association 2012 meetings, and Eastern Finance Association 2012 meetings for their helpful comments. All errors are our own. 


\section{Introduction}

Prior literature has argued that CEO-specific styles of management play an important role in shaping corporate decisions (Bertrand and Schoar, 2003, Malmendier and Tate, 2005). CEOspecific styles stem from values, norms, habits, and tastes that are likely to be fundamentally shaped by religion. Religion promotes a set of beliefs and actions that guide important aspects of the lives of its followers. Religious instruction typically begins in early childhood and is regularly reinforced throughout an individual's life. Despite its importance, the impact of a CEO's religion on corporate decisions has not been properly investigated due to a lack of data regarding CEO's religious affiliations. In this paper, we fill this gap in the literature.

Early economists, such as Adam Smith and Karl Marx, have discussed the importance of religion in shaping economic behavior. Stulz and Williamson (2003) argue that cultural and religious forces affect individual beliefs and preferences. As such, we would expect to find a significant difference in the risk profiles of corporate decisions made by CEOs from different religious backgrounds. In particular, Stulz and Williamson (2003), Weber (1930), and others argue that Protestantism, when compared to Catholicism, encourages entrepreneurship and greater risk tolerance. These fundamental differences between Protestants and Catholics are not just recent empirical observations, but are supported by the historical developments of these religions and are ingrained in the cultural and ethical principles of their religious identities (Anderson, Drakopoulou-Dodd, and Scott, 2000; Egnal, 1996; Nunziata and Rocco, 2014; Rietveld and Van Burg, 2013). In this study, we follow and build on these arguments in the literature.

Specifically, as Protestants are more entrepreneurial and Kihlstrom and Laffont (1979) show that lower risk aversion engenders entrepreneurship, the argument suggests that Protestants 
are likely to be less risk averse. For example, Weber (1930), through an analysis of the forces behind the historical developments of modern European economies, suggests that the Protestants were greater risk-takers than Catholics. Hirshleifer and Thakor (1992) define a preference for safe decisions by managers as "managerial conservatism." Therefore, we test the hypothesis that Catholic CEOs are more conservative in their corporate decisions than Protestant CEOs. Furthermore, as corporate policies based on personal biases may reduce the profitability of a firm, we explore the implications of these decisions on firm value.

Broadly speaking, there are three sets of decisions that corporations make: 1) capital structure, 2) diversification, and 3) investments. If Catholic CEOs are more conservative in their corporate actions, then they should decrease leverage, increase diversification, and decrease investments (e.g., R\&D). Furthermore, the behavioral consistency theory (Cronqvist, Makhija, and Yonker, 2012) states that individuals tend to behave consistently across different situations. As a result, these differences in managerial conservatism should also be visible in the personal actions of the CEOs, such as CEO ownership of the shares of the firms.

To test these hypotheses, we hand collect CEOs' self-reported religious affiliations from different volumes of Marquis Who's Who. We identify the religious affiliations for 457 CEOs from 1992-2010. There does not appear to be an obvious selection bias as there are no statistically significant differences on a number of dimensions between our sample and that from ExecuComp. Specifically, the age and tenure of CEOs in our sample are similar to those of the average ExecuComp CEOs. Moreover, the average firm in our sample is similar to that in ExecuComp in terms of size, leverage, business segments, capital expenditures, market-to-book ratios, and stock return volatility. Our empirical estimates indicate that firms with Catholic CEOs have lower leverage, issue debt (equity) less (more) frequently, increase diversification measured 
through business segments and geographic segments, invest less in both capital expenditures and R\&D, and personally own fewer shares in their firms. Taken together, these results are consistent with the idea that Catholic CEOs tend to be more conservative in their corporate decisions than Protestant CEOs. Additionally, we find that these corporate decisions are significantly negatively associated with firm valuation. After Catholic CEOs undertake these decisions, their firms exhibit lower Tobin's Q and reduced profitability.

There are studies that question the empirical methodologies employed by earlier work investigating managerial style, including those of Bertrand and Schoar (2003). Fee, Hadlock, and Pierce (2013) find that the standard F-test on a joint set of manager-specific dummy variables often employed in prior studies to identify managerial style effects is inappropriate and suffers from endogeneity concerns. In those studies, the CEO dummy variable used when the CEO changes firms may be picking up similarities between the old firm and the new firm and not managerial style. In our study, we do not employ this methodology. Instead, we match the observations using propensity scores to compare very similar firms, except that they differ in the religious affiliation of their CEOs. This method has been found to be generally empirically reliable (Smith and Todd, 2005; Roberts and Whited, 2012).

We undertake a number of additional steps to correct for possible endogeneity concerns. Following Guiso, Sapienza, and Zingales (2003), we use the Second Vatican Council as an instrument. The Second Vatican Council (or Vatican II) has had a substantial effect on Catholicism. For example, the use of local languages in Mass was allowed and laymen were encouraged to participate in certain rituals. These changes resulted in Catholics having a clearer understanding of the Church's teachings and traditions. Guiso et al. (2003) suggest that Catholics born after the creation of Vatican II received a different education and style of preaching than 
those born prior to it. In contrast, there should be no such effect on Protestant CEOs. Our findings remain robust to this methodology.

Furthermore, to account for unobserved factors that are time invariant, we present robustness tests that include firm fixed effects. Our results continue to hold, suggesting that the estimates are not driven by a non-random assignment of CEO religiosity. Additionally, we conduct difference-in-difference tests to identify the effect of CEO change on corporate policy. First, we compare the changes in characteristics between firms that experience a change in CEO (from Protestant to Catholic) and the firms where the new CEO belongs to the same religion as the old CEO. Then, we compare the changes in characteristics between the firms that experience a change in CEO (from Catholic to Protestant) and the firms where the new CEO belongs to the same religion as the old CEO. Our contention that Catholic CEOs are more conservative in their decisions and policies continues to hold.

We perform out-of-sample tests using Hofstede's (2001) country-level cultural measures to evaluate whether these findings regarding the differences in risk-aversion of Catholic and Protestant CEOs are robust. We find that the uncertainty avoidance index is significantly higher for Catholic countries, as compared to Protestant countries. This indicates that the behavior of the CEOs in our sample is representative of the preferences of the general Catholic and Protestant populations. Finally, we examine the preferences of CEOs for sports that may lead to personal injury. We find that Protestant CEOs are more likely to engage in riskier sporting activities.

This study provides evidence that the religious affiliations of CEOs affect corporate decisions through conservative corporate policies. The primary implication of our findings is that a CEOs' religion can help to partially address some of the empirical puzzles regarding why firms 
in the same industry that are similar in size, opportunities, and governance display significant differences in capital structure, diversification, investments, and CEO stock ownership.

There are a number of recent studies that empirically investigate the relationship between the religiosity in the location of the firm and corporate decision making concerning investments (Hilary and Hui, 2009), executive compensation (Kuhnen and Niessen, 2012), option grants to corporate executives (Kumar, Page, and Spalt, 2011), earnings management (Dyreng, Mayew, and Williams, 2012) and tax avoidance (McGuire, Omer, and Sharp, 2010). These studies use county-level measures of religiosity, including differentiating between Catholicism-majority and Protestant-majority counties, and draw implications for firm behavior. However, these studies propose that the religious beliefs and viewpoints of the majority of the inhabitants in a county will be reflected in corporate decisions without demonstrating a channel through which the county's culture affects firm decisions. For example, if a Catholic CEO in a Protestant majority county adopts policies that do not conform to the Protestant culture, it is not clear how the Protestant majority of that county will enforce its culture on the CEO. In fact, our results indicate that the religious beliefs and viewpoints of the majority of the inhabitants in a county are not always reflected in corporate decisions. In our study, the channel through which culture affects corporate decisions (i.e., the preferences of the CEOs) is explicit and well documented in the corporate finance literature.

Another major drawback of the literature is that it uses a county-level variable to proxy for a manager's preference. However, any county-level variable represents an array of county characteristics that may lead to possible identification biases making these results less reliable. Our study makes a unique contribution to the literature by hand collecting individual CEO's religious affiliations and testing the hypothesized relationships directly. 
The rest of the study is structured as follows. Section II reviews the literature and presents the predictions. Section II describes the data collection and variable construction. Section IV tests the predictions linking corporate decisions and CEO's religious affiliations. Section V subjects the results to robustness tests, while we provide our conclusions in Section VI.

\section{Literature Review and Empirical Predictions}

There is a vast strand of literature, starting with Adam Smith, that explores the relationship between religion and economic outcomes. In his seminal work, Weber (1930) argues that economic outcomes vary significantly depending on the Catholic or Protestant religious affiliations of the people. Discussing this literature would require volumes. Here, we briefly summarize the most relevant arguments for our study.

\section{A. Economics and Religious Denominations}

Weber (1930) hypothesizes that Protestantism led to the rise of capitalism due to its work-ethic, thrift, individualism, and the encouragement of wealth accumulation. ${ }^{1}$ A large number of later studies, including recent articles by Arrunada (2010) and Blum and Dudley (2001), have investigated and found evidence supporting Weber's (1930) hypotheses. Other studies have proposed additional reasons for the differences between Catholics and Protestants. Putnam (1993) and La Porta, Lopez-de-Silanes, Shleifer, and Vishny (1997) find that Catholicism inhibits trust resulting in poorer economic outcomes, such as decreased GDP and

\footnotetext{
${ }^{1}$ Weber (1930) argues that a core tenet in Calvinistic Protestantism is double pre-destination. The belief here is that from the beginning, God chooses who will go to heaven and hell. However, human beings don't know their destiny so wealth accumulation (and working hard to achieve it) is taken as sign of destiny.
} 
government efficiency. Stulz and Williamson (2003) find that Protestantism is associated with better country level protection of creditor rights. A recent study by Becker and Woessmann (2009) attributes better economic outcomes to Protestant attitude toward learning. However, Weber's (1930) seminal work has also been criticized for misrepresenting Protestantism and Catholicism. For example, Guiso et al. (2003) do not find empirical support for some of Weber's (1930) hypotheses.

Researchers have also noted significant differences in the individual behaviors and decisions among Catholics and Protestants in education (Steen and Dubbink, 1994), fertility (Lehrer, 1996), union formation (Sanders, 1995), divorce (Thornton, 1985), and personal finance (Renneboog and Spaenjers, 2012). The goal of our study is to add to this area of research by examining the corporate decisions of individual CEOs who belong to these two denominations.

\section{B. Religion and Risk Aversion - the Debate in the Literature}

There are studies that demonstrate, using location-based indicators, that residents in Protestant counties in the U.S. behave as if they are more risk averse than residents in Catholic counties. A good example is the study by Kumar et al. (2011). Using the religious affiliation of the majority of the people in the county as proxy, they find that Catholics tend to buy lottery-type stocks in greater numbers. However, these findings did not settle the debate regarding religion and risk aversion in the literature. In contrast, Renneboog and Spaenjers (2012), using survey data, find that Catholic households are more risk averse and invest less frequently in stocks.

Divergence in the results is also found using different measures for religiosity. Halek and Eisenhauer (2001) use survey data to determine that Protestants are generally less risk averse. Breuer, Hens, Salzmann, and Wang (2013) find that households in Protestant countries tend to 
have larger debt maturities. In contrast, Barsky, Juster, Kimball, and Shapiro (1997), using survey data, and Benjamin, Choi, and Fisher (2010), in a laboratory setting, find that Catholicism reduces risk aversion.

Halek and Eisenhauer (2001) provide guidance regarding the reconciliation of these differences in the literature. They find that the relationship between Catholicism and risk aversion depends upon the type of risk. They empirically determine that Catholics and Jews generally display greater risk aversion, but are more tolerant toward tail risk or speculative risk. Playing games of chance in a survey setting, buying lottery tickets, or investing in stocks with features similar to a lottery, as studied in Kumar et al. (2011), are examples of speculative risk. The topic of our study, the corporate decisions of CEOs, is not about tail risk and, as such, occupies a somewhat different space in the literature than Kumar et al. (2011).

\section{Religion and Managerial Conservatism}

There are causal links between managerial conservatism and the choice of religious denomination. Stulz and Williamson (2003), Weber (1930), and others argue that Protestantism, when compared to Catholicism, encourages entrepreneurship and more risk tolerance. These fundamental differences between Protestants and Catholics are supported by the historical development of these religions and are ingrained in the cultural and ethical principles of their religious identities. In providing empirical evidence linking Protestantism to greater degrees of entrepreneurship, Nunziata and Rocco (2014) note that Protestants, both in the Calvinistic and Lutheran traditions, emphasize work of every kind, not only that directly related to the Church, as honorable, necessary, and a service to God. Consequently, Protestants view upward mobility and accumulation of worldly possessions as hints of salvation (Mayer and Sharp, 1962). Thus, 
there exists a differential effect of the Protestant ethic on the propensity for entrepreneurship (Anderson et al., 2000; Egnal, 1996; Nunziata and Rocco, 2014; Rietveld and Van Burg, 2013).

The theoretical entrepreneurship literature typically uses risk aversion as the primary variable differentiating the general population from entrepreneurs with entrepreneurs as less risk averse (Parker, 2005) and acting in the face of uncertainty (Kihlstrom and Laffont, 1979). Other entrepreneurial traits, like hard work, are theoretically derived to be the results of risk aversion. For example, Parker, Belghitar, and Barmby (2005) determine that entrepreneurs respond to earnings uncertainty by working harder and, as such, make the deterministic part of their income larger.

As Protestants are more entrepreneurial and the entrepreneurial spirit engenders less risk aversion, the argument suggests that Protestants are likely less risk averse. For example, Weber (1930), through an analysis of the forces behind the historical developments of modern European economies, suggests that Protestants were greater risk takers than Catholics. Furthermore, Stulz and Williamson (2003) argue that cultural and religious forces affect individual beliefs and preferences. Thus, we would expect to find a significant difference in the risk profiles of corporate decisions made by CEOs from different religions.

In our research, we compare the corporate decisions of CEOs and find that the risk profiles of these actions vary significantly depending upon the religious affiliations of the CEO. Therefore, it is important to understand the null hypotheses. By any measure, CEOs are some of the most qualified employees available in the economy. They are successful winners among their peers, as explained by the CEO tournament literature. The null hypotheses states that the religious affiliation of CEOs does not matter; that is, there are no systematic differences in the actions of CEOs along the religious affiliation space. In our results, we reject the null. However, 
we do not and cannot claim that Catholic CEOs do not take risks or Protestant CEOs take excessive risks. We simply find that there are systematic differences in the actions of the CEOs, which is consistent with general cultural differences found between Catholics and Protestants (Hofstede, 2001).

\section{CEO's Preferences and Corporate Decisions}

The behavioral theories explain the divergence between the predictions of neoclassical theories and empirical observations through the biases of decision makers. Some prominent examples of the biases include CEO's style (Bertrand and Schoar, 2003), CEO's overconfidence (Malmendier and Tate, 2005), CEO’s ability (Murphy and Zabojnik, 2004), CEO’s talent (Gabaix and Landier, 2008), and CEO's resoluteness (Bolton, Brunnermeier, and Veldkamp, 2008). In this paper, we explore the impact of the bias that arises when some CEOs prefer "safe" decisions (i.e., decisions that have a low probability of early failure). Hirshleifer and Thakor (1992) define this bias as managerial conservatism.

There are three major sets of corporate decisions: 1) financing, 2) diversification, and 3) investments. Let's first consider financing decisions. Decreasing financial leverage decreases the risks of the firm. The standard explanation for this link between leverage and risk is that if the firm fails to honor interest payments, it may face bankruptcy and the CEO may lose his job. Thus, a conservative action by a CEO is to decrease leverage (or maintain a low level of leverage). A decrease in leverage can occur if the firm retires debt and perhaps increases equity.

The second set of corporate decisions is diversification. Diversification adds segments to the firm, and may reduce the correlation of the different streams of cash flows within the firm (May, 1995; Tufano, 1996). This decline in the correlation reduces the cash flow volatility of the 
firm thereby decreasing its probability of failure. Thus, a conservative CEO may choose to increase diversification.

In addition, $R \& D$ and capital expenditures are two significant corporate investment decisions. Since the ex-ante probability of success of a project is highly uncertain, R\&D expenditures are considered even more risky. As a result, a CEOs' conservatism may be more of an issue when determining how much to invest in R\&D.

The managerial conservatism of the decision-makers, in this case the CEOs, should also be reflected in their personal choices. Cronqvist et al. (2012) find that CEOs behave consistently in their personal and professional actions. Therefore, we can expect that the conservative actions of CEOs should also manifest in their personal decisions, such as stock ownership. A large component of the compensation for CEOs is linked to the firms' equity. As Baxamusa (2011) points out, since his compensation, reputation, and employment are all contingent on firm performance, this equity component of their compensation increases the CEOs' risk. Thus, a conservative CEO should attempt to reduce his exposure by decreasing his stock ownership of the firm.

Finally, the decisions of the CEOs affect firm value. If corporate decisions are influenced by the biases of the CEOs and do not reflect the needs of the business, these decisions will most likely lead to a decline in the firm's performance. For instance, if a conservative CEO reduces the leverage of the firm due to personal preferences and puts less weight on the tax benefits of leverage, then it should reduce the value of the firm.

In summary, our central argument is that the religious characteristics of CEOs can affect corporate decisions. If Catholics tend to be more conservative than Protestants, firms with 
Catholic CEOs are more likely to have less leverage, lower debt issuance, more equity issuance, more diversification, less R\&D, less capital expenditures, and less shareholding.

\section{Data Collection and Descriptive Statistics}

\section{A. Religious Affiliations and Activities of the CEOs}

The data on the religious affiliations of CEOs are hand collected from different volumes of Marquis Who's Who. Marquis Who's Who is of interest to us as it contains biographical information of CEOs of both publicly listed and privately listed firms. These annually published books provide detailed information regarding career progressions, professional achievements, religious affiliations, activities, interests and hobbies, and other biographical information on a large number of leaders and achievers throughout the world. Marquis Who's Who collects this data from annual questionnaires that it sends to the above mentioned group. Thus, the information is self-reported.

Our list of CEOs whose biographies were searched in Marquis Who's Who is taken from ExecuComp. ExecuComp provides names, positions, affiliations, and compensation data for publicly listed firms that are constituents of the S\&P 1500 index. Since there are a number of people with the same name, the first name, the last name, and the company name have to match in Marquis Who's Who database to be included in our sample. Additionally, some of these executive biographies are present in some volumes, but not in others. As such, we search all of the different volumes to identify the religious affiliations of the CEOs. In our sample period, ExecuComp has 5,496 CEOs listed in it. We are able to identify the religious affiliations of 652 CEOs. The primary reason for the drop in the number of observations is that the vast majority of 
CEOs do not disclose their religious affiliation. In Section III.D., we determine whether the sample is representative of the data in ExecuComp.

We compare the sample CEO's religious affiliations to that of the general population of the U.S. in Table I, Panel A. Column (1) reports the statistics from the country profile page of the Association of Religion Data Archives (ARDA: http://www.thearda.com/). The data from ARDA has been used by Hilary and Hui (2009) and Kumar et al. (2011). Column (1) reports that Christianity is the dominant religion with about $81 \%$ of the population adhering to it in the U.S. The CEO sample reflects this fact with $73 \%$ of the CEOs reported as being Christians. Column (2) suggests that the Jews are over-represented in the CEO sample as Jewish CEOs constitute $12.5 \%$ of the sample, while the total Jewish population in the U.S. is only $1.7 \%$. No doubt fundamental differences exist in the corporate decisions of Christian and Jewish (or Hindu) CEOs. We leave this investigation for future research. In this research, we only focus on the dominant religions in the U.S.

We identify CEOs who self-report as Roman Catholics as Catholics. ARDA reports that there are at least 181 non-Catholic Christian denominations. Thus, for empirical estimation purposes, we separate Protestant denominations from other Christian denominations [e.g., Mormons (4 CEOs), Unitarists (one CEO)] and lump all non-Catholic, non-Other Christian adherents together and call them Protestants. The CEOs classified as non-Christians and OtherChristian CEOs are then removed from the sample. We provide a breakdown of the CEOs belonging to the Protestants group in Table I, Panel B. Episcopalian, Presbyterian and Methodist CEOs together account for about $70 \%$ of the Protestant CEOs. Finally, we construct the dummy variable Catholic CEO, which is equal to one if the CEO belongs to the Catholics group and is 
zero otherwise. Table I, Panel B finds that the percentage of Catholic CEOs in the sample is $42.34 \%$.

Insert Table I about here.

Table I, Panel C presents some additional characteristics of the CEOs including gender, age, and tenure in their current positions. This data are from ExecuComp. The results indicate that the CEOs who report their religious affiliations are overwhelmingly male. There is no significant difference in the average ages of the CEOs belonging to Catholic or Protestant denominations. However, the average tenure of Catholic CEOs is about one and a half years shorter than that of Protestant CEOs. Finally, Table I, Panel D presents the political affiliations of the CEOs. There are more Republican CEOs than Democrats.

\section{B. CEO Ownership Variables}

To construct measures of CEO firm-specific stockholdings and trading activities, we follow Jenter (2005) and Baxamusa (2011). Own is the ratio of the total number of stocks (including options) of the firm owned by the CEO and the total number of stocks outstanding of the firm. Alternatively, the variable Trading captures the number of abnormal stocks purchased by CEOs in that particular year. Trading is calculated as the change in the number of shares owned, minus the number of shares obtained from option exercises, minus the number of shares from stock grants divided by the lagged number of stocks excluding options owned by the CEO. Panel A in Table II presents a summary of these two variables. The results indicate that Catholic 
CEOs have lower stockholdings when compared to Protestant CEOs. Furthermore, Protestant CEOs are more active in accumulating their equity stakes in the firms they manage.

Insert Table II about here.

\section{Firm-Specific Variables}

The source of our firm-specific accounting data is Compustat. After merging the religious affiliation data with the Compustat items, we are left with 2,406 firm-year observations from 457 firms from 1992-2010. We use CRSP data to calculate the volatility of the stocks and obtain board characteristics data from IRRC. We present the summary statistics of the variables, sorted on the religious affiliations of the CEOs, in Panel B of Table II. The firms with Catholic CEOs have statistically significantly lower amounts of debt in their capital structure (as captured by Debt/MVA) and they issue less debt annually (as captured by Debt Issue). These firms also have lower amounts of investments (Cap Ex.), tangible assets (Tangibility), and profit margin (Profitability). Catholic CEOs have greater power within their firms, while there are also more Catholic CEOs who are founding members of their firms.

We utilize the Compustat Segments database to compute the diversification measures of the firms. Business Segment Total is the total number of business segments of the firm. Business Segment SIC 4 is the total number of business segments that have different four-digit SIC codes. Business Segment SIC 2 is the total number of business segments that have different two-digit SIC codes. Next, we identify the number of different geographical segments, as represented by Geog. Segment. Finally, we compute the variable Total Segments to reflect the total number of 
different segments, both business and geographical. According to Panel B of Table II, the firms led by Catholic CEOs have greater numbers of business segments and geographical segments.

\section{Comparison to the Average ExecuComp Firm}

As the sample consists only of those CEO's who voluntarily report their religious affiliations, the possibility exists that the sample is not representative of the population of CEOs as a whole. If CEOs randomly report their religious affiliations to Marquis Who's Who, then our sample averages should represent average CEOs characteristics. Thus, our results could be generalized. A test for it is to compare our sample averages to those of all of the firms reported in ExecuComp.

Using a different sample, Kini and Williams (2012) report the average age of CEOs is 55.28 years. Table II, Panel C, Column (1) reports the average age of all CEOs in ExecuComp for our sample years to be 55.21 years. Table I, Panel C, Column (1) reports our sample's CEOs average age to be 55.35 years. The difference between our sample average and the ExecuComp average is not statistically significant and is reported in Column two of Table II, Panel C. We also examine the differences between our sample and that of all of the firms in ExecuComp using variables that describe the firms' key characteristics, such as firm size, stock return volatility, book leverage, etc. The differences reported in the third column are not statistically significant. The implication here is that the CEO sample averages and the averages of ExecuComp are statistically similar. Therefore, the CEO sample is representative of the data in ExecuComp.

\section{E. CEOs and Religious Clustering in Counties}


The current literature (Kumar et al., 2011) has largely assumed that the average CEO in a county in which a large proportion of the population is Catholic (or Protestant) should also be Catholic (Protestant). The possible reason, as Hilary and Hui (2009) suggest, is that firms tend to hire employees who are congruent to its culture and tend to weed out employees who are not. If this channel is at work, then we should see a clustering of Catholic CEOs in Catholic counties and a clustering of Protestant CEOs in Protestant counties. Thus, we should observe a significant correlation between a Catholic (Protestant) proportion of a population and the CEO's Catholic (Protestant) affiliation. A direct measure of a county's religious preferences, which has been widely used in the literature, is the ratio of Catholic adherents to Protestant adherents. We find that the correlation of this ratio with CEO's Catholic affiliation is about 3\% and is statistically not different from zero. This correlation is very small, indicating that there does not seem to be a clustering of Catholic (Protestant) CEOs in Catholic (Protestant) counties as is assumed in the literature.

\section{Testing Strategies and Results}

\section{A. Empirical Models}

We build on the univariate analyses reported in Table II by formally testing the relationships using a multivariate regression methodology. In our sample, there are few firms for which we have information on the religious affiliations of both the previous CEO and the current CEO. A fixed effects panel regression model estimates within firm variations. As such, the identification comes from changes in CEOs as the firm's fixed effects would subsume the variations of the dummy variable representing the CEO's religious affiliation. In other words, the dummy variable for the CEO's religious affiliation in a firm fixed effects model would only 
capture the common characteristics of the limited number of observations in which there is a change in the religious affiliations of the current and the past CEOs. To avoid this issue, we use ordinary least square regressions. We control for the panel nature of the data by clustering the standard errors at the firm level. Additionally, we would like to emphasize that we get qualitatively similar results using fixed effects regression models. We present some of these results in Table XII. Later, in our robustness section, we also report regression results when CEOs change.

In an ideal experiment, we would have two sets of firms. One set of firms would be treated, while the other set would be untreated. Of course, the treatment would be applied randomly. However, in our study, it is possible that firms and the CEOs' with certain religious affiliations may not be matched randomly. There are two ways to overcome the possible bias resulting from such a situation. In the first method, the control firms are selected to match the main characteristics of the treated firms. The second method treats this potential issue as an omitted variable bias and overcomes it by including the inverse Mills ratio as an independent variable. In the main body of the paper, we present empirical estimates obtained from the first methodology by using a propensity score matched set of control firms. The Catholic CEO-firms are matched to Protestant CEO-firms on size, industry, and year. The general empirical model in our study is as follows:

$$
\begin{aligned}
{\text { Corporate } \text { Action }_{i, t}} & =\alpha+\beta \text { Catholic CEO }_{i, t}+\gamma^{j} \text { CEO }_{j, i, t}+\delta^{k} \text { Agency }_{k, i, t-1} \\
& +\mu^{l} \text { Location }_{l, i, t-1}+\theta^{m} \text { Industry }_{m, i, t-1}+\varphi^{n} \text { Years }_{n, t}+\varepsilon_{i, t}
\end{aligned}
$$


Here, Corporate Action is a vector of corporate decisions that CEOs undertake. These actions, as discussed previously, include leverage, debt issuance, equity issuance, diversification, capital expenditures, $\mathrm{R} \& \mathrm{D}$, and stock ownership. We are particularly interested in $\beta$, the estimated coefficient of Catholic CEO. In this specification, $C E O$ is a vector of $\mathrm{CEO}$ characteristics, such as gender and age. These variables have been shown to be correlated with religious participation. The literature finds that females and older people, on average, tend to be more religious. Additionally, Powell and Ansic (1997) find that men tend to be less conservative.

Adams, Almeida, and Ferreira (2005) and Morse, Nanda, and Seru (2011) find empirical evidence to support their arguments that powerful CEOs can induce the board to change its position to the detriment of shareholders. Following Morse et al. (2011) and Adams et al. (2005), we create an index, CEO Power, that increases by one unit if the CEO is the Chairman or the President and increases by two units if the CEO holds both of these titles. Adams et al. (2005) also suggest that founders who continue as CEO exercise a relatively large influence on corporate decisions with the board, generally deferring to the founder-CEO. Thus, we include a dummy variable Founder $C E O$ that takes a value of one if the CEO is also a founding member of the firm.

We also include CEO's tenure as a proxy for possible agency problems. We enter the number of directors in the firm and its squared value, and denote them as Director and Director ${ }^{2}$, in our regression equations to control for the effectiveness of the boards. We also include various firm characteristics as controls, since varying business needs may require firms to act in a particular fashion regardless of the CEO's preferences. For instance, smaller firms, firms with a higher market-to-book ratio, higher profitability, more tangible assets, and less financial constraints can undertake less conservative actions. In addition, we include the standard 
deviation of stock returns as a proxy for firm-specific risks. Location controls for the region's impact on firms decisions. Two controls are used: 1) the county's religiosity (defined as the ratio of Catholics to Protestants in a county) and 2) per capita income. We lag these variables by one time period to mitigate possible endogeneity problems. Additionally, year and industry dummies are used in all regressions, but not reported in the tables.

As we interpret the results, we should keep in mind that the design of our empirical models involves calculating the differences in the decisions of Catholic and Protestant CEOs. We cannot comment on what types of CEOs are adhering to the more optimal policies due to the obvious problem associated with defining the optimum. The goal of our study is modest. We simply want to establish that there exist systematic differences in the way Catholic and Protestant CEOs form their decisions and these decisions are consistent across different situations.

\section{B. Capital Structure Decisions and CEO's Religion}

To determine whether there are any significant differences in the capital structure decisions of firms led by Catholic and Protestant CEOs, we estimate standard leverage regressions. There are various measures used in the literature to estimate the level of leverage in a firm. Among them, the book value of leverage and the market value of leverage are most widely used. Both of these measures of leverage have been criticized for a variety of reasons. Welch (2004) notes that market leverage has a mechanical relationship with stock price and, as such, may not be a managerial choice variable. Alternatively, total assets on the balance sheet are reported at their historical values and may not reflect the true market value of the assets. As a result, the book value of leverage may not be a true reflection of the leverage of the firm. We use 
both of these definitions to make sure that our results are consistent regardless of the definition used. The estimates are presented in Table III.

Insert Table III about here.

In Table III, the variable of interest is the dummy variable Catholic CEO. The empirical testing model has been enhanced with the median industry leverage, since Frank and Goyal (2009) report it to be one of the most important determinants of capital structure. ${ }^{2}$ The regression results in Table III are consistent with our predictions. The first three columns report the results without any control variables except for firm size, a constant, and year dummies. The next three columns report the results with all of the control variables included. The estimated coefficient of Catholic CEO is negative and statistically significant in each of the six columns. In terms of economic magnitude, it appears that the presence of a Catholic CEO decreases Debt/MVA by $1.7 \%$ in Column (4).

In terms of the other control variables reported in Table III, size, market-to-book, profitability, and median industry leverage are all statistically significant. Their signs and significance match those in Frank and Goyal (2009). The results indicate that larger firms, firms with lower growth opportunities as measured by market-to-book ratios, less profitable firms, and firms in industries with more leverage have higher leverage. Firms with greater CEO power have statistically significantly less Debt/AT.

Next, we dig deeper by examining both the debt and equity issuance decisions of the firms. If Catholic CEOs are associated with lower leverage, then they can do so by retiring debt

\footnotetext{
${ }^{2}$ An incomplete, but extensive list of the most prominent papers that deal with the determinants of capital structure includes Frank and Goyal (2010) and Rajan and Zingales (1995).
} 
and issuing more equity. We test this premise by utilizing a logit regression model for panel data. In our regressions, Debt Issue or Equity Issue is the dependent variable, while the independent variables include Catholic CEO and the other control variables. The results are reported in Table IV.

Insert Table IV about here.

Columns (1) and (3) of Table IV report the results involving debt issuance, while Columns (2) and (4) report the results for equity issuance. The first two columns in the table present regressions with Catholic $C E O$ and Size as the independent variables, while the last two columns utilize all relevant controls. The results clearly indicate that firms managed by Catholic CEOs are less (more) likely to issue debt (equity) than those under the management of Protestant CEOs.

\section{Diversification and CEO's Religion}

A typical CEO has a large, undiversified position in the firm he leads. As a result, he may attempt to lower this idiosyncratic risk by diversifying the operations of the firm. A conservative CEO may be even more inclined to do so. As a result, if conservative CEOs prefer more conservative policies in the firms, we would expect to observe a positive relationship between the indicator Catholic CEO and various measures of diversification.

In the literature, empirical measures of diversification typically use data from Compustat Industry Segments File (Dennis, Dennis, and Sarin, 1997; Comment and Jarrel, 1995). The firms have some discretion as to how they classify products in the different SIC industries. Thus, we 
consider different measures of diversification that include business segments and geographical segments. The results are reported in Table V. The estimated coefficients of the Catholic CEO dummy are positive and statistically significant in each of the five columns. The results indicate that firms with Catholic CEOs are more diversified. For example, Column (5) reports that the presence of a Catholic CEO increases the number of segments by 0.51 .

Insert Table V about here.

Among the other control variables included in the regression models, indicators of financial constraints and the firm's stock volatility are statistically significant in most of the columns implying that financially constrained and risky firms are generally less diversified. The results also indicate that large firms are more diversified. These estimates are consistent with previous studies on this topic. We also observe that firms where CEOs are also founding members have statistically significant larger numbers of business, geographic, and total segments.

\section{Investments and CEO's Religion}

Next, we investigate the impact of a CEO's religion on the firm's investment decisions. Table VI reports the estimates from regressing R\&D and capital expenditures on the Catholic $C E O$ dummy and the other control variables. Following convention, $\mathrm{R} \& \mathrm{D}$ is set equal to zero when Compustat reports it as a missing variable. The literature has shown that companies that do not report R\&D expenditures usually have insignificant spending on R\&D (Himmelberg, Hubbard, and Palia, 1999; Aggarwal and Samwick, 2006). 
Insert Table VI about here.

The estimated values of the coefficient of Catholic CEO are negative and statistically significant in all of the specifications. These results indicate that Catholic CEOs invest less in R\&D and capital expenditures. This is consistent with a greater degree of conservatism in the decisions of Catholic CEOs.

Among the control variables, it appears that more profitable firms increase their investments. Profitability can also be a proxy for internally generated cash flows. As such, this estimate is consistent with the well documented investment and cash flow relationship. Founder CEOs invest less in R\&D expenditures. Additionally, financial constraints reduce both of these types of investments. These results essentially verify what has been reported in the literature.

\section{E. CEO's Shareholding and Religion}

A conservative CEO can reduce his own exposure to the firm by reducing his stockholdings in the firm. If our hypothesis holds, we should observe a negative relationship between stock ownership of the CEO and the Catholic CEO dummy. We use two indicators to measure this behavior. The first variable is the percentage of the firm the CEO owns. The second variable is the CEO's trading activity. Table VII reports that the estimated coefficient of Catholic CEO is negative and statistically significant at the $1 \%$ confidence level in each of the four columns. Column (3) reports that Catholic CEOs own $0.72 \%$ less stock in the firm as compared to Protestant CEOs. This is economically significant as the table on summary statistics reports 
that the average CEO owns only $2.32 \%$ of the firm. Thus, it appears that Catholic CEOs reduce their personal risk by owning less stock in the firm.

\section{F. Firm Value and CEOs Religion}

The conservative actions of the CEO can have significant impact on the values of the firm. If a CEO is more conservative than necessary, it may negatively impact the earnings of the firm and investors will value the firm accordingly. In our next set of tests, we attempt to determine whether the conservative actions of CEOs are indeed correlated with the profitability and valuation of the firms. We consider a measure of the current operating profit of the firm, Profit and Tobin's $Q$. Table VIII, Panels A and B report the results of the relationship between the firm's profitability, Tobin's Q, and the interaction term of religious affiliations of the CEO and the actions of the CEO. We are interested in the effects of the actions of the CEOs on future profitability and Tobin's Q. As a result, the independent variables of interest are entered as first difference. Panel A, Columns (1) and (2) report that the estimates of Catholic CEO interacted with change in leverage are positive and statistically significant. The estimates are negative and statistically significant for the interaction terms of Catholic CEO and change in business segments in Panel A, Columns (3) and (4). Panel B, Columns (1) and (2) indicate that the interaction terms of Catholic CEO and change in investments are positive and statistically significant. Finally, the estimates in Panel B, Columns (3) and (4) find that the interaction terms of Catholic CEO and change in percentage ownerships are positive and statistically significant.

Insert Table VIII about here. 
The results are consistent with our hypotheses. When a firm with a Catholic CEO reduces the level of leverage, increases the number of business segments, or reduces investments, it is negatively associated with the firm's current profitability and future growth potential. Therefore, these decisions by the CEO are costly to the shareholders.

\section{Robustness Tests}

\section{A. Alternate Testing Strategy: The Impact of New CEOs}

The channel through which Hilary and Hui (2009), Kumar et al. (2011), and others explain how religiosity affects various financial decisions depends upon the assertion that the prevalent culture of the county where the firm is located affects its decisions. The argument for this linkage is that corporate decisions are guided by corporate culture and corporate culture is built on the behavior and preferences of the stakeholders. A firm located in a particular county should have a large proportion of the stakeholders who are from that area and, it follows, from the dominant religion of that area. We devise a test for this assertion.

For illustration purposes, let's use a firm where the old CEO is Catholic (or a Protestant) and reflects the dominant viewpoint of the location of the firm. If the new CEO comes from a Protestant (or a Catholic) background and if the viewpoints of the majority of the people of the location are to be reflected in the decisions of the firm, then there should not be any significant changes in the policies and actions of the firm in terms of the risk profiles. However, if the personal preferences of the CEO dominate the influence of the culture of the area, then we should observe that our findings presented thus far are validated. The advantage of this strategy is that firm characteristics, like the firm's asset composition and contract obligations, should remain relatively similar, while the variable of interest, the $\mathrm{CEO}$, changes. 
To implement this empirical strategy, we identify two sets of difference-in-difference tests. In the first set of tests, we use those firms where the old CEO was a Protestant, while the new CEO is a Catholic. We compare their changes in policies to the changes in policies of a control group of firms where the new CEO belongs to the same religion as the old CEO. We utilize the values of the dependent variables for the year prior to and the year after a change in CEO. We carefully remove those CEOs whose predecessor's religious affiliation is unknown. These removals lead to a reduction in sample size. As this study uses a large number of dependent variables, for brevity of presentation, we report a limited set of the results in Table IX. Specifically, we display one regression equation from each group. It would be appropriate to point out that our analyses provide similar results in all of the other dependent variables we utilized in our study.

\section{Insert Table IX about here.}

We present the regression estimates for the first set of tests in Panel A of Table IX. If our original results are robust, we would expect to observe a negative and significant coefficient estimate to the indicator variable $\triangle$ Catholic CEO when the dependent variables are $\triangle D e b t / M V A$, $\triangle C a p E x$, and $\Delta O w n$ and a positive and statistically significant coefficient estimate when the dependent variable is $\triangle B$ usiness Segment. The estimates indicate that when the new CEO belongs to the Catholic religion, the firm decreases leverage, increases the number of business segments, decreases capital expenditures, and the CEO decreases his own shareholdings of the firm. The results are as expected and, as such, our original conclusions are strongly supported. 
In the second set of tests, we use those firms where the old CEO was a Catholic and the new CEO is a Protestant. The members of the control group include the new CEO who belongs to the same religion as the old CEO. The estimates are presented in Panel B of Table IX. We expect to find a positive and significant coefficient estimate to the indicator variable $\Delta$ Catholic $C E O$ when the dependent variables are $\triangle D e b t / M V A, \triangle C a p E x$., and $\triangle O w n$ and a negative and statistically significant coefficient estimate when the dependent variable is $\Delta B$ usiness Segment. The regression estimates indicate that when the new CEO belongs to the Protestant religion, the firm increases leverage, decreases the number of business segments, increases capital expenditures, and the CEO increases his own shareholdings of the firm. These estimates provide further support for our findings that Catholic CEOs are more conservative in their decisions even under these categorizations. Our results are consistent with Guiso, Sapienza, and Zingales's (2006) assertion that people tend to maintain their cultural preferences even when they immigrate to a different country.

The results presented in this section question the strength of the assumption of Hilary and Hui (2009), Kumar et al. (2011), and others as to how the religious beliefs of the location affect corporate behavior. There are three possible reasons for the differences between our results and those reported in some papers that use location specific dummy variables to proxy for the religious affiliation of the CEO (Kumar et al., 2011). First, there are no obvious enforcement mechanisms to punish a CEO who deviates from the cultural norms of the location. In fact, Bebchuk and Fried (2005) note that it is extremely difficult for stakeholders to restrict a CEO's behavior due to entrenchment. The second reason involves the government protection of employees. There are strong legal protections afforded to employees from any discrimination with respect to differences in religious affiliations. Thus, a large population of Catholics or 
Protestants within an area may not increase the chances of a Catholic or Protestant CEO candidate landing the job. This is supported by our finding that the correlation between the religiosity of the county (as measured by the proportion of the population that is Catholic divided by the proportion that is Protestant) and the number of Catholic CEOs is very small and not statistically significant. Another reason for the differences in our results may lie in the significant number of firms located in cosmopolitan metropolitan statistical areas (such as New York City) where it is relatively easier to find adherents of many different religions in large numbers. Thus, the cultural impact of the county's majority religion might be diluted due to the cosmopolitan nature of the county. However, it is important to note that we cannot and do not claim that the cultural preferences of the location of the firm have no impact on corporate decisions. Our results simply demonstrate that it is the cultural preferences of CEOs that predominantly affect firm decisions.

In the regression estimates presented here, we compare the differences in the respective variables between the year prior to and the year after CEO changes. However, it could be argued that one year may not be enough for a CEO to effectively imprint his own preferences on the firm's decisions. In unreported tables, we replicate these regressions with differences in the variables between the year prior to and three years after a CEO change. The results largely hold.

\section{B. Alternate Measures of Risk}

Thus far, to examine the link between a CEO's religious affiliation and risk aversion, we use capital structure, diversification, investment, and ownership decisions as proxies for risk. Even though these are reasonable measures, we can also follow the methodology in Hilary and Hui (2009) and use more direct measures of firm risk, such as the standard deviation of stock 
returns and the standard deviation of ROA. We do that in an unreported table (available upon request). We calculate the standard deviation of monthly stock returns and the standard deviation of ROA over a five-year rolling window. The regression estimates indicate that firms led by Catholic CEOs have lower stock return volatility and lower ROA volatility. These results are fully consistent with our original findings.

\section{Replicability: International Evidence}

To validate our results, we consider widely-used survey evidence gathered by Hofstede (2001). In an effort to identify cross-country cultural differences, Geert Hofstede conducted a psychological survey of employee values from 1967-1973. The survey participants were IBM employees in 72 countries and included about 88,000 respondents. In terms of both the range of countries and the number of respondents involved, his indices are regarded as the most comprehensive (Kagitcibasi, 1997). Hofstede (2001) classifies cultures into five dimensions: 1) individualism, 2) masculinity, 3) power distance, 4) uncertainty avoidance, and 5) long-term orientation. The uncertainty avoidance index (hereafter, UAI) is most closely relevant to our study. As Hofstede (2001) discusses, "Uncertainty Avoidance Index deals with a society's tolerance for uncertainty and ambiguity. ... It indicates to what extent a culture programs its members to feel either uncomfortable or comfortable in unstructured situations. ... Uncertainty avoiding cultures try to minimize the possibility of such situations by strict laws and rules, safety and security measures, and on the philosophical and religious level by a belief in absolute Truth." 
The data are from Geert Hofstede's personal website. ${ }^{3}$ To identify the religious composition of the countries, we use the Religion and State database maintained by the Association of Religion Data Archives (ARDA). Catholic Country is a dummy variable if the majority of the population in a country adheres to the Catholic denomination. \% Catholic is the percentage of the population who are Catholics. Similarly, \%Protestant is the percentage of the population who are Protestants. Finally, we collect country characteristics from La Porta, Lopezde-Silanes, Shleifer, and Vishny (2008) and Boyd and Jalal (2012). GDP is the average of the PPP-adjusted GDP per capita from 1980-2008. Corrupt is the average corruption score from 1996-2000. Privo is the ratio of private credit to GDP, an average of 1999-2003. UK Origin is the British legal origin of the countries.

Panel A of Table X provides a summary of the country-specific variables. The Uncertainty Avoidance Index is statistically significantly higher for Catholic countries. While there does not appear to be significant differences in the level of development between Protestant and Catholic countries, Catholic countries are less likely to have British legal origins.

To identify whether this UAI differs on the basis of religion, we estimate more formal OLS regression models using the index as the dependent variable. Panel B of Table X presents the regression estimates of all of the countries in the sample, while Panel $\mathrm{C}$ reports the results where we consider only Christian-majority countries. The coefficients of Catholic Country and \% Catholic are both positive and statistically significant. Alternatively, the coefficient of $\%$ Protestant is negative and statistically significant. The results are robust to the inclusion of various control variables. Furthermore, these results hold whether the sample contains all of the countries of the world or only the Christian-majority countries. Therefore, it is clear that even in

\footnotetext{
${ }^{3}$ http://www.geert-hofstede.com/
} 
a widely-used survey of cultural dimensions, we find support for our central premise that Catholics tend to display greater uncertainty avoidance when compared to Protestants. These results in an out-of-sample setting support the strength of our findings.

Insert Table $\mathrm{X}$ about here.

To determine whether there are significant differences in any of Hofstede's (2001) other cultural dimensions on the basis of religious affiliation of the citizens and to see which factors matter the most, we conduct a logit regression analysis. Specifically, we estimate logistic regressions using the Catholic Country dummy as the dependent variable. We include the five cultural dimensions of Hofstede (2001) as independent variables of interest. The cultural dimensions are PDI (the power distance index), IDV (individualism vs. collectivism), MAS (masculinity vs. femininity), UAI (uncertainty avoidance index), and PRA (pragmatic vs. normative, previously called long-term orientation). The results are presented in Table X, Panel D. In Columns (1)-(5), we enter the cultural norms one at a time. In Column (6), we enter all the cultural norms together. The results indicate that only UAI enters the regressions significantly, at the $5 \%$ level. This indicates that, culturally speaking, only the uncertainty avoidance index exhibits systemic differences based on the Catholic vs. Protestant religiosity of the countries represented in the sample.

\section{Consistency: CEO's Personal Choices}

One way to determine whether Catholic CEOs are more conservative in their preferences is to observe the type of recreational activities they choose. To this end, we collect information 
on the hobbies, sporting activities, political party affiliations, and military service records of the CEOs from our database. The indicator variable Risky Sports is equal to one if, under the category of hobbies, the CEOs report sky diving, bungee jumping, rock climbing, scuba diving, hang gliding, parachute jumping, hiking, flying, sky surfing, skiing, white water canoeing, football, field hockey/lacrosse, and gambling. Alternatively, the indicator variable Non-Risky Sports takes a value of one if the CEOs do not belong to the Risky Sports category and report any of the following as a hobby: photography, walking, coin collecting, stamp collecting, art, painting, athletics, rowing, bowling, table tennis, tennis, golf, and reading. These classifications of activities have been compiled from Berti (2004), Zarevski, Marusic, Zolotic, Bunjevac, and Vukosav (1998), and the National Institute on Drug Abuse (NIDA). ${ }^{4}$

A simple summary of the activities and interests of the CEOs are presented in Panel A of Table XI. Protestant CEOs participate more in Risky Sports. However, there is no discernible difference in the participation in Non-Risky Sports among the two groups. These results suggest that Protestant CEOs may be less conservative in their choice of sports than Catholic CEOs. In addition to the summary statistics, we conduct a formal logit regression analysis to determine whether the link between risky sports and religious affiliation holds even after controlling for a number of other confounding effects. The results are presented in Table XI, Panel B. The estimates are consistent with our previous findings that Protestant CEOs appear to be less conservative in their choice of risky sports than the Catholic CEOs.

Insert Table XI about here.

\footnotetext{
${ }^{4}$ http://archives.drugabuse.gov/nida notes/nnvol10n4/MeasureSens.html
} 


\section{E. Endogeneity}

Our empirical models regress corporate decisions on observed CEO and firm characteristics. However, it is possible that some CEO or firm characteristics are not fully observable. These unobserved omitted variables can lead to endogeneity (Fee et al., 2013) and, as such, may bias the estimates. Moreover, there exists heterogeneity in the firm's environment. This heterogeneity may affect the contract between the CEO and the firm. For example, unobserved variations among the firms can simultaneously drive the selection of a CEO and firm policies. One way to rule out these concerns is to use firm fixed effects (Himmelberg et al., 1999). Coles and Li (2013) find that if the omitted characteristic is time constant, then fixed effects methodology mitigates such bias. In our sample, the time period is not too long. Thus, the firm fixed effects are likely to capture both unobserved fixed and slowly changing firm characteristics. A further advantage of using firm fixed effects is that it will remove any locationspecific effects. For example, Hilary and Hui (2009) suggest that Catholic CEOs are more likely to work in Catholic counties. Employing firm fixed effects methodology will mitigate any such bias.

Another potential empirical issue with regression analyses in the CEO literature is that CEOs are not randomly assigned to different firms. In his seminal paper, Heckman (1979) demonstrates that this selection issue leads to an omitted variable bias. Heckman (1979) suggests using the inverse Mills ratio as an additional control variable to mitigate selection issues. Thus, we augment the firm fixed effects model with an inverse Mills ratio.

Following Guiso et al. (2003), we use the Second Vatican Council as the instrument to generate the inverse Mills ratio. If a CEO is born on or before 1960, the dummy variable takes a 
value of one. Guiso et al. (2003) use 1960 as the cut off year since children must be at least of a certain age before they can attend classes or understand the preaching.

The motivation for Vatican II was to arrest the increasing secularization of Catholics, mainly in Europe and North America, and make Catholicism more relevant to its followers. Gihleb and Giuntella (2013) describe this rare event as a "religious earthquake." The Council aimed to make Catholicism more accessible to its adherents by updating the major features of Catholic doctrines and practices making these doctrines more pertinent to the followers' everyday lives. As a result of the presentation of Holy Mass in a vernacular language and the participation of laymen in the various activities of the church, the adherents not versed in Latin, who previously did not fully comprehend the messages of the Church, now had a clearer understanding of its teachings and traditions.

It is important to note that the Church did not change its viewpoints on major social issues like contraception as part of Vatican II. Thus, there is mixed evidence regarding whether the Catholic Church was better able to retain its adherents (Kelley, 1978). What is clear is that Vatican II resulted in a better understanding of the religious doctrines of the Catholic Church. The net impact is an increase in the Catholic identity through the recognition of its traditions by its existing adherents. Voye (1999) concludes that there is an increase in invoking Catholicism to affirm the identity of cities, regions, and even the European continent. Consequently, we expect that Catholic CEOs born after 1960 will have a better understanding of the Catholic traditions and teachings. Similarly, Guiso et al. (2003) argue that because of the Council, the education and values received by Catholic CEOs born after 1960 will be different from that of CEOs born prior to Vatican II. As a result, Vatican II is a good instrument as it affects corporate policy only through the CEO's religious affiliations. 
This instrument meets the exclusion restriction as the birth dates of the CEOs falling before or after 1960 should be random and relatively orthogonal to the firm's corporate policies. No doubt younger CEOs might be less risk averse. However, this concern is mitigated by applying the dummy variable to Protestant CEOs. We estimate the inverse Mills ratio by running a probit of the Catholic Dummy on the year 1960 dummy and employing other controls used in this research. ${ }^{5}$

The estimates of the Catholic CEO dummy reported in Table XII are similar in terms of sign and statistical significance as those reported in the previous tables. The estimates of Table XII suggest that the results are robust to the use of firm fixed effects. These results are not surprising and are consistent with our previous findings. Our results support the statement by Guiso et al. (2006) that "beliefs, values, and social constraints that ethnic, religious, and social groups transmit fairly unchanged from generation to generation." This statement highlights that values and beliefs transmitted through religion are persistent and are not likely to change. Guiso et al. (2003) find that people who are raised religiously exhibit the same beliefs and preferences, even when they reject religion as adults. In fact, the religious affiliation of CEOs is truly one of the few exogenous variables available in corporate finance.

As selection and endogeneity concerns are important in the corporate finance literature, in unreported tables, we have conducted a number of further empirical tests, such as an endogenous regime switching model, to perform a joint test of endogeneity and selection. We find that our results are always robust. Thus, our results do not appear to be driven by selection and endogeneity.

\footnotetext{
${ }^{5}$ In unreported results, we find that Cragg-Donald F- statistics reject the null that Vatican II is a weak instrument.
} 


\section{Conclusion}

In this paper, we examine the corporate actions of Catholic CEOs and their impact on firm value. Using a sample of hand collected data on the religious affiliations of CEOs, we find strong evidence that firms with Catholic CEOs behave differently from those with Protestant CEOs. Firms with Catholic CEOs have lower leverage, issue debt (equity) less (more) frequently, increase diversification as measured through business segments and geographic segments, invest less in both capital expenditures and R\&D, and own less stock of the firms. Overall, the results are consistent with the assertion that Catholic CEOs are more conservative than Protestant CEOs and the activities of the firms reflect this difference in their actions and decisions. Additional tests using individual preferences for sporting activities verify this observation. Using Hofstede's (2001) cultural dimensions, we find that the uncertainty avoidance index is significantly higher for Catholic countries, which is consistent with our central findings. We also determine that the conservative actions of Catholic CEOs are associated with reduced

firm value. We conclude that the personal preferences of a CEO have a significant impact on corporate decisions. 


\section{References}

Adams, R., H. Almeida, and D. Ferreira, 2005, "Powerful CEOs and Their Impact on Corporate Performance," Review of Financial Studies 18(4), 1403-1432.

Aggarwal, R. and A. Samwick, 2006, "Empire-Builders and Shirkers, Investment, Firm Performance and Managerial Incentives," Journal of Corporate Finance 12, 489-515.

Anderson, A., S. Drakopoulou-Dodd, and M. Scott, 2000, "Religion as an Environmental Influence on Enterprise Culture: The Case of Britain in the 1980s," International Journal of Entrepreneurial Behavior and Research 6(1), 5-20.

Arrunada, B., 2010, "Protestants and Catholics: Similar Work Ethics Different Social Ethics," Economic Journal, 120(547), 890-918.

Barsky, R., F. Juster, M. Kimball, and M. Shapiro, 1997, "Preference Parameters and Behavioral Heterogeneity: An Experimental Study in the Health and Retirement Study," Quarterly Journal of Economics 112, 537-579.

Baxamusa, M., 2011, "How Well Do Market Timing, Catering and Classical Theories Explain Corporate Decisions?" Journal of Financial Research, 34(2), 217-239. 
Bebchuk, L. and J. Fried, 2005, "Pay Without Performance: Overview of the Issue," Journal of Corporate Law 30, 647-673.

Becker, S. and L. Woessmann, 2009, “Was Weber Wrong? A Human Capital Theory of Protestant Economic History," Quarterly Journal of Economics, 531-596.

Benjamin, D., J. Choi, and G. Fisher, 2010, “Religious Identity and Economic Behavior,” NBER Working Paper 15925.

Berti, J., 2004, “A Review of Band Biological Correlates of Sensation Seeking,” Journal of Research in Personality 38(3), 256-279.

Bertrand, M. and A. Schoar, 2003, "Managing with Style: The Effect of Managers on Firm Policy," Quarterly Journal of Economics 158(4), 1169-1208.

Blum, U. and L. Dudley, 2001, “Religion and Economic Growth: Was Weber Right?” Journal of Evolutionary Economics 11, 207-230.

Bolton, P., M. Brunnermeier, and L. Veldkamp, 2008, “Leadership, Coordination and MissionDriven Management,” Columbia University Working Paper.

Boyd, J. and A. Jalal, 2012, “A New Measure of Financial Development: Theory Leads Measurement," Journal of Development Economics 99, 341-357. 
Breuer, W., T. Hens, A. Salzmann, and M. Wang, 2013, “On the Determinants of Household Debt Maturity Choice," SSRN Working Paper \#1753351.

Coles, J. and Z. Li, 2013, "Managerial Attributes, Incentives and Performance," SSRN Working Paper \#1680484.

Comment, R. and G. Jarrell, 1995, “Corporate Focus and Stock Returns,” Journal of Financial Economics 37, 67-87.

Cronqvist, H., A. Makhija, and S. Yonker, 2012, "Behavioral Consistency in Corporate Finance: CEO Personal and Corporate Leverage," Journal of Financial Economics 103(1), 20-40.

Dennis, D., D. Dennis, and A. Sarin, 1997, “Agency Problems, Equity Ownership, and Corporate Diversification," Journal of Finance 52, 1350-1360.

Dyreng, S., W. Mayew, and C. Williams, 2012, "Religious Social Norms and Corporate Financial Reporting,” Journal of Business Finance \& Accounting 39(7-8), 845-875.

Egnal, M., 1996, Divergent Paths: How Culture and Institutions Have Shaped North American Growth, Oxford, UK, Oxford University Press. 
Fama, E. and K. French, 1992, “The Cross-Section of Expected Stock Returns,” Journal of Finance 47(2), 427-465.

Fee, C., C. Hadlock, and J. Pierce, 2013, "Managers With and Without Style: Evidence Using Exogenous Variation," Review of Financial Studies 26(3), 567-601.

Frank, M. and V. Goyal, 2009, “Capital Structure Decisions Which Factors are Reliably Important," Financial Management 38, 1-37.

Gabaix, X. and A. Landier, 2008, “Why has CEO Pay Increased So Much?” Quarterly Journal of Economics 123(1), 49-100.

Gihleb, R. and O. Giuntella, 2013, "Nuns and the Effects of Catholic Schools: Evidence from Vatican II,” IZA Discussion Paper \#7753.

Guiso, L., P. Sapienza, and L. Zingales, 2003, “People’s Opium? Religion and Economic Attitude," Journal of Monetary Economics 50(1), 23-48.

Guiso, L., P. Sapienza, and L. Zingales, 2006, “Does Culture Affect Economic Outcomes?” Journal of Economic Perspective 20(2), 225-282.

Halek, M. and J. Eisenhauer, 2001, "Demography of Risk Aversion,” Journal of Risk and Insurance 68(1), 1-24. 
Heckman, J., 1979, “Sample Selection Bias as a Specification Error,” Econometrica 47(1), 153161.

Hilary, G. and K. Hui, 2009, "Does Religion Matter in Corporate Decision Making in America?" Journal of Financial Economics 93(3), 455-473.

Himmelberg, C., R. Hubbard, and D. Palia, 1999, "Understanding the Determinants of Managerial Ownership and Value," Journal of Financial Economics 53, 353-384.

Hirshleifer, D. and A. Thakor, 1992, "Managerial Conservatism, Project Choice and Debt," Review of Financial Studies 5(3), 437-470.

Hofstede, G., 2001, Culture's Consequences: Comparing Values, Behaviors, Institutions and Organizations Across Nations, Thousand Oaks, CA, SAGE Publications.

Jenter, D., 2005, “Market Timing and Managerial Portfolio Decisions," Journal of Finance 60(4), 1903-1949.

Kagitcibasi, C., 1997, "Individualism and Collectivism," Handbook of Cross-Cultural Psychology Vol. 3, Boston, MA, Allyn and Bacon. 
Kaplan, S. and L. Zingales, 1997, "Do Investment Cash-Flow Sensitivities Provide Useful Measures of Financial Constraint?” Quarterly Journal of Economics 112, 169-215.

Kelley, M., 1978, "Why Conservative Churches are Still Growing," Journal for the Scientific Study of Religion 17(2,) 165-172.

Kihlstrom, R. and J. Laffont, 1979, “A General Equilibrium Entrepreneurial Theory of Firm Formation Based on Risk Aversion," Journal of Political Economy 87, 719-748.

Kini, O. and R. Williams, 2012, “Tournament Incentives, Firm Risk and Corporate Policies," Journal of Financial Economics 103, 350-376.

Kuhnen, C. and A. Niessen, 2012, "Public Opinion and Executive Compensation," Management Science 58(7), 1249-1272.

Kumar, A., J. Page and O. Spalt, 2011, "Religious Beliefs, Gambling Attitudes, and Financial Market Outcomes," Journal of Financial Economics102(3), 671-708.

La Porta R., F. Lopez-de-Silanes, A. Shleifer, and R. Vishny, 1997, "Trust in Large Organizations," American Economic Review 87, 333-338.

La Porta R., F. Lopez-de-Silanes, A. Shleifer, and R. Vishny, 2008, “The Economic Consequences of Legal Origins," Journal of Economic Literature 46(2), 285-332. 
Lehrer, E., 1996, "Religion as a Determinant of Fertility,” Journal of Population Economics 9, 173-196.

Malmendier, U. and G. Tate, 2005, “CEO Overconfidence and Corporate Investments,” Journal of Finance 60(6), 2661-2700.

May, D., 1995, “Do Managerial Motives Influence Firm Risk Reduction Strategies?” Journal of Finance 50, 1291-1308.

Mayer, A. and H. Sharp, 1962, "Religious Preference and Worldly Success," American Sociological Review 27(2), 218-227.

McGuire, S., T. Omer, and N. Sharp, 2010, “The Impact of Religion on Financial Reporting Irregularities," The Accounting Review87(2), 645-673.

Morse, A., V. Nanda, and A. Seru, 2011, “Are Incentive Contracts Rigged by Powerful CEOs?” Journal of Finance 66(5), 1779-1821.

Murphy, K. and J. Zabojnik, 2004, “CEO Pay and Turnover: A Market Based Explanation of Recent Trends," American Economic Review Papers and Proceedings 94, 192-196. 
Nunziata, L. and L. Rocco, 2014, “The Protestant Ethic and Entrepreneurship: Evidence from Religious Minorities from the Former Holy Roman Empire,” University of Padua Working Paper.

Parker, S., 2005, “The Economics of Entrepreneurship: What We Know and What We Don't,” Foundations and Trends in Entrepreneurship 1(1), 1-54.

Parker, S., Y. Belghitar and T. Barmby, 2005, "Wage Uncertainty and the Labor Supply of SelfEmployed Workers," Economic Journal 115(502), C190-C207.

Powell, M. and D. Ansic, 1997, “Gender Differences in Risk Behavior in Financial DecisionMaking: An Experimental Analysis," Journal of Economic Psychology18, 605-628.

Putnam, R., 1993, Making Democracy Work: Civic Traditions in Modern Italy, Princeton, NJ, Princeton University Press.

Rajan, R. and L. Zingales, 1995, "What Do We Know About Capital Structure? Some Evidence from International Data," Journal of Finance 50, 1421-1460.

Renneboog, L. and C. Spaenjers, 2012, "Religion Economic Attitude and Household Finance," Oxford Economic Papers 64(1), 103-127. 
Rietveld, C. and E. Van Burg, 2013, "Religious Beliefs and Entrepreneurship Among Dutch Protestants,” SSRN Working Paper \#2338857.

Roberts, M. and T. Whited, 2012, "Endogeneity in Empirical Corporate Finance," SSRN Working Paper, Abstract No. 1748604.

Sanders, W., 1995, The Catholic Family: Marriage, Children, and Human Capital, Boulder, CO: Westview Press.

Shu, T., J. Sulaeman, and E. Yeung, 2012, "Local Religious Beliefs and Mutual Fund Risk Taking Behavior," Managerial Science 58(10), 1779-1796.

Smith, J. and P. Todd, 2005, "Does Matching Overcome LaLonde's Critique of Nonexperimental Estimators?" Journal of Econometrics 125(1-2), 305-353.

Steen, T. and K. Dubbink, 1994, "The Impact of Religion on the Earnings and Human Capital of Women." Presented at the meetings of Midwest Economic Association, March 24-26, Chicago, IL.

Stulz, R. and R. Williamson, 2003, “Culture, Openness, and Finance,” Journal of Financial Economics 70(3), 313-349. 
Thornton, 1985, “Changing Attitude Towards Separation and Divorce: Causes and Consequences," American Journal of Sociology 90(4), 142-168.

Tufano, P., 1996, “Who Manages Risk? An Empirical Examination of Risk Management Practices in the Gold Mining Industry,” Journal of Finance 51, 1097-1137.

Voye, L., 1999, "Secularization in a Context of Advanced Modernity," Sociology of Religion $60(3), 275-288$.

Weber, M., 1930, The Protestant Ethics and the Spirit of Capitalism, London, UK, Allen and Unwin.

Welch, I., 2004, “Capital Structure and Stock Returns,” Journal of Political Economy 112, 106131.

Zarevski, P., I. Marusic, S. Zolotic, T. Bunjevac, and Z. Vukosav, 1998, “Contribution of Arnett's Inventory of Sensation Seeking and Zuckerman's Sensation Seeking Scale to the Differentiation of Athletes Engaged in High and Low Risk Sports," Personality and Individual Differences 25, 763-768. 


\section{Table I. Religious Denomination and Personal Characteristics of the CEOs}

Panel A. Comparing the Sample CEO Religious Affiliations with that of the General Population The general population religious affiliation statistics is from http://www.thearda.com/internationalData/countries/Country 234 1.asp and is presented in Column (1). The ARDA data are for the survey year 2010. Column (2) represents the comparable percentages for the CEO's sample which is hand collected from Marquis Who's Who. The total number of CEOs used in Column (2) is 652. In Column (1), Hindus are reported under the "Other" category. In Column (2), no CEOs reported themselves as belonging to the Agnostic category.

\begin{tabular}{lcc}
\hline & Population & CEO Sample \\
\hline & $\mathbf{( 1 )}$ & $\mathbf{( 2 )}$ \\
\hline Protestant & 53.3 & 40.6 \\
Catholic & 23.9 & 29.5 \\
Other & 3.6 & 2.9 \\
\cline { 2 - 3 } Total Christian & 80.8 & 73.0 \\
& & \\
Agnostic & 13.5 & N/A \\
Jewish & 1.7 & 12.5 \\
Muslim & 1.3 & 1.5 \\
Buddhist & 1.3 & 2.3 \\
Hindu & N/A & 3.4 \\
Other & 1.4 & 7.3 \\
Total & 100 & 100 \\
\hline
\end{tabular}

Panel B. Top Five Protestant Denominations

The top ten denominations as percentages of the total number of CEOs who self-report as belonging to Protestantism are reported in the following table.

\begin{tabular}{llc}
\hline & Protestant Denomination & \% of Protestant CEOs \\
\hline & \multicolumn{1}{c}{$(\mathbf{1})$} & $\mathbf{( 2 )}$ \\
\hline 1$)$ & Episcopalian & 26.82 \\
2) & Presbyterian & 25.67 \\
3) & Methodist & 17.62 \\
$4)$ & Lutheran & 8.81 \\
5) & Baptist & 6.13 \\
\hline
\end{tabular}

Panel C. Additional Characteristics of the CEOs

Gender is a dummy variable that takes a value of one if the CEO is a male. Age is the age of the CEO, while Tenure is the number of years a person has been the $\mathrm{CEO}$ of the firm. * and ** represent statistical significance at 5\% and $1 \%$ levels, respectively.

\begin{tabular}{lcccc}
\hline & Combined & Catholic & Protestant & $\mathbf{( 3 )}-\mathbf{( 2 )}$ \\
\hline & $\mathbf{( 1 )}$ & $\mathbf{( 2 )}$ & $\mathbf{( 3 )}$ & $\mathbf{( 4 )}$ \\
\hline Gender (Male) & 0.9864 & 0.9851 & 0.9874 & 0.0023 \\
Age & 55.3542 & 55.0631 & 55.5749 & 0.5117 \\
Tenure & 7.1028 & 6.3029 & 7.7089 & $1.4060^{* *}$ \\
Obs. & 457 & 197 & 260 & \\
\hline
\end{tabular}

Panel D. Number of Republican and Protestant CEOs

A Republican CEO is a CEO who self-reports his political affiliation in Marquis Who's Who as republican. A Democrat CEO is a CEO who self-reports his political affiliation as democrat.

\begin{tabular}{lcc}
\hline & Catholic & Protestant \\
\hline & $\mathbf{( 1 )}$ & $\mathbf{( 2 )}$ \\
\hline Republican & 69 & 130 \\
Democrat & 14 & 15 \\
Total & 83 & 145 \\
\hline
\end{tabular}




\section{Table II. Sample Characteristics}

Panel A. Stock Ownership and Trading Decisions

This table reports the relationship between stock ownership and stock trading decisions and the Catholic religious affiliation of the CEO in the U.S. We use 2,406 firm-year observations from 457 firms from 1992-2010 for our study. Means are reported. Own is the ratio of the total number of stocks (including options) of the firm owned by the CEO and the total number of stocks outstanding of the firm. Trading is the change in the number of shares owned less the number of shares obtained from option exercises and less the number of shares from stock grants (similar to Jenter, 2005 and Baxamusa, 2011). This number is divided by the lagged number of stocks excluding options owned by the CEO. The tails of all of the variables (except the dummy variables) are winsorized at the $0.5 \%$ level. $*$ and $* *$ represent statistical significance at the $5 \%$ and $1 \%$ levels, respectively.

\begin{tabular}{lcccc}
\hline Variable & Combined & Protestant CEO & Catholic CEO & $\mathbf{( 3 )}-(\mathbf{2})$ \\
\hline & $\mathbf{( 1 )}$ & $\mathbf{( 2 )}$ & $\mathbf{( 3 )}$ & $\mathbf{( 4 )}$ \\
\hline Own & 0.0285 & 0.0366 & 0.0198 & $-0.0168^{* *}$ \\
Trading & 0.0973 & 0.1993 & -0.0432 & $-0.2425^{* *}$ \\
\hline
\end{tabular}


Panel B. Summary Statistics of Firm Characteristics

This table reports the relationship between corporate decisions and the Catholic religious affiliation of the CEO in the U.S. We use 2,406 firm-year observations from 457 firms from 1992-2010. Catholic CEO is a dummy variable that takes a value of one if the CEO reports himself to be a Catholic. Protestant CEO is a dummy variable that takes a value of one if the CEO reports himself to be a Protestant. Means are reported. Debt is long-term debt of the firm. MVA is the market value of the assets of the firm. The market value of assets is the sum of the market value of equity plus debt in current liabilities plus long-term debt plus the liquidation value of the preferred stock less the deferred taxes and the investment tax credit. $A T$ is the total assets of the firm. $T D$ is the total debt comprised of long-term debt plus debt in current liabilities. Director is the number of directors of the firm. Market-to-Book is the ratio of $M V A$ and $A T$. Tangibility is the ratio of net property, plant, and equipment and AT. Profit is the ratio of operating income before depreciation and AT. Debt Issue is a dummy variable that takes a value of one if long-term debt issuance less long-term debt reduction is more than $1 \%$ of the total assets of the firm. Equity Issuance is a dummy variable that takes a value of one if the sale of common stock less the purchase of common stock is greater than $1 \%$ of the total assets. Business Segment Total is the total number of business segments of the firm. Business Segment SIC 4 is the total number of business segments that have different fourdigit SIC codes. Business Segment SIC 2 is the total number of business segments that have different two-digit SIC codes. Geog. Segment is the total number of geographical segments. Total Segments is the total number of different segments. Cap Ex. is the capital expenditures of the firm divided by the total assets. $R \& D$ is the research and development expenditures of the firm divided by total assets. CEO Power is an index that increases by one unit if the CEO is the chairman or president of the company. This index increases by two units if the CEO is both the chairman and the president of the company. Founder CEO is a dummy variable that takes a value of one if a founding member is still the CEO of the company. Stock Volatility is the standard deviation of the monthly stock returns (excluding dividends). A rolling five-year window is used to calculate these returns. County Religiosity is the percentage of the total population of the county that adheres to a religion (Hillary and Hui, 2009). Per Capita Income is the natural log of the per capita income of that county. Size is the log of total assets. The tails of all of the variables (except the dummy variables) are winsorized at the $0.5 \%$ level. *and ** represent statistical significance at $5 \%$ and $1 \%$ levels, respectively.

\begin{tabular}{lcccc}
\hline \multicolumn{1}{c}{ Variable } & Combined & Protestant CEO & Catholic CEO & (3) - (2) \\
\hline & $\mathbf{( 1 )}$ & $\mathbf{( 2 )}$ & $\mathbf{( 3 )}$ & $\mathbf{( 4 )}$ \\
\hline Debt/MVA & 0.1917 & 0.1964 & 0.1849 & $-0.0114^{* *}$ \\
Debt/AT & 0.2248 & 0.2263 & 0.2228 & -0.0035 \\
TD/MVA & 0.2622 & 0.2684 & 0.2533 & -0.0151 \\
Debt Issue & 0.4388 & 0.4568 & 0.4132 & $-0.0435^{*}$ \\
Equity Issue & 0.1117 & 0.1107 & 0.1130 & 0.0023 \\
Business Segment Total & 1.9640 & 1.8015 & 2.1942 & $0.3927^{* *}$ \\
Business Segment SIC 4 & 1.6421 & 1.5280 & 1.8046 & $0.2766^{* *}$ \\
Business Segment SIC 2 & 1.2110 & 1.1170 & 1.3449 & $0.2279^{* *}$ \\
Geog. Segment & 2.3211 & 2.2361 & 2.4420 & $0.2059^{* *}$ \\
Total segments & 4.7145 & 4.4993 & 5.0208 & $0.5215^{* *}$ \\
Cap Ex. & 0.0592 & 0.0638 & 0.0527 & $-0.0110^{* *}$ \\
R\&D & 0.0369 & 0.0380 & 0.0361 & -0.0021 \\
CEO Power & 1.1464 & 1.1066 & 1.1730 & $0.0664^{*}$ \\
Founder CEO & 0.0191 & 0.0076 & 0.0251 & $0.0175^{*}$ \\
Director & 8.2172 & 8.1657 & 8.2904 & $0.1246^{*}$ \\
Market-to-Book & 2.0556 & 2.0635 & 2.0444 & -0.0190 \\
Tangibility & 0.3078 & 0.3197 & 0.2909 & $-0.0289^{* *}$ \\
Profit & 0.1305 & 0.1345 & 0.1249 & $-0.0096^{* *}$ \\
Stock Volatility & 0.0233 & 0.0261 & 0.0194 & $0.0066^{* *}$ \\
County Religiosity & 0.5042 & 0.5091 & 0.5066 & -0.0025 \\
Per Capita Income & 9.9602 & 9.9431 & 9.9653 & $0.0221^{*}$ \\
Size & 8.0317 & 8.0429 & 8.0157 & -0.0272 \\
\hline
\end{tabular}


Panel C. Comparing CEO Sample Means to those from ExecuComp

Column (1) reports the average of all firms reported in ExecuComp from 1992-2010. Financial and utility firms are excluded. These variables are winsorized at the $0.5 \%$ level. Column (2) reports the difference between Column (1) in this panel and the averages reported in Table I, Panel (C), Column (1). Column (3) reports the difference between Column (1) in this panel and the averages reported in Table II, Panel (B), Column (1). * and ** represent statistical significance at 5\% and $1 \%$ levels, respectively.

\begin{tabular}{lccc}
\hline \multicolumn{1}{c}{ Variable } & ExecuComp & (1)-Table IC Column (1) & (1)-Table IIB Column (1) \\
\hline Age & $\mathbf{( 1 )}$ & $\mathbf{( 2 )}$ & $\mathbf{( 3 )}$ \\
Tenure & 55.2114 & -0.1428 & \\
Debt/AT & 7.0315 & -0.0713 & 0.0033 \\
Business Segment SIC 4 & 0.2281 & & -0.0337 \\
Cap Ex. & 1.6084 & & 0.0007 \\
R\&D & 0.0599 & & 0.0006 \\
Market-to-Book & 0.0375 & & -0.0382 \\
Stock Volatility & 2.0174 & & 0.0004 \\
Size & 0.0237 & & -0.0409 \\
\hline
\end{tabular}




\section{Table III. Capital Structure and Religious Affiliation}

This table reports the relationship between leverage and the Catholic religious affiliation of the CEO in the U.S. We use 2,406 firmyear observations from 1992-2010. The matched sample of Catholic and Protestant CEOs is used. Matching is performed on size, the Fama-French (1992) 49 industries, and year. Gender is a dummy variable that takes a value of one if the CEO is male. Age is the age of the CEO. Tenure is the number of years that this person has been the CEO of the firm. Director ${ }^{2}$ is the square of the number of directors. Industry Leverage is the median industry leverage. Industry and year dummies are used, but not reported. Standard errors are robust and clustered for firms and are reported in parentheses below the coefficients. Year dummies are used, but not reported. * and ** represent statistical significance at $5 \%$ and $1 \%$ levels, respectively.

\begin{tabular}{|c|c|c|c|c|c|c|}
\hline & Debt/MVA & Debt/AT & TD/MVA & Debt/MVA & Debt/AT & TD/MVA \\
\hline & $(1)$ & (2) & (3) & (4) & (5) & (6) \\
\hline \multirow[t]{2}{*}{ Catholic CEO } & -0.0174 & -0.0133 & -0.0049 & -0.0131 & -0.0107 & -0.0031 \\
\hline & $(0.0064)^{* *}$ & $(0.0045)^{* *}$ & $(0.0021)^{* *}$ & $(0.0042)^{* *}$ & $(0.0037)^{* *}$ & $(0.0002) * *$ \\
\hline \multirow[t]{2}{*}{ Size } & 0.0006 & 0.0009 & 0.0012 & 0.0023 & 0.0051 & 0.0029 \\
\hline & $(0.0022)$ & $(0.0021)$ & $(0.0031)$ & $(0.0027)$ & $(0.0038)$ & $(0.0031)$ \\
\hline \multirow[t]{2}{*}{ Gender } & & & & 0.1044 & 0.0939 & 0.1079 \\
\hline & & & & $(0.0290)^{* *}$ & $(0.0313)^{* *}$ & $(0.0212)^{* *}$ \\
\hline \multirow[t]{2}{*}{ Age } & & & & -0.0010 & -0.0017 & -0.0007 \\
\hline & & & & $(0.0007)$ & $(0.0007)^{*}$ & $(0.0006)$ \\
\hline \multirow[t]{2}{*}{ CEO Power } & & & & -0.0195 & -0.0282 & -0.0177 \\
\hline & & & & $(0.0123)$ & $(0.0137)^{*}$ & $(0.0123)$ \\
\hline \multirow[t]{2}{*}{ Founder CEO } & & & & -0.0086 & -0.0212 & 0.0179 \\
\hline & & & & $(0.0277)$ & $(0.0327)$ & $(0.0333)$ \\
\hline \multirow[t]{2}{*}{ Tenure } & & & & -0.0039 & -0.0009 & -0.0002 \\
\hline & & & & $(0.0031)$ & $(0.0006)$ & $(0.0006)$ \\
\hline \multirow[t]{2}{*}{ Director } & & & & 0.0053 & 0.0175 & 0.0010 \\
\hline & & & & $(0.0162)$ & $(0.0225)$ & $(0.0171)$ \\
\hline \multirow[t]{2}{*}{ Director $^{2}$} & & & & -0.0007 & -0.0003 & -0.0001 \\
\hline & & & & $(0.0010)$ & $(0.0010)$ & $(0.0002)$ \\
\hline \multirow[t]{2}{*}{ Market-to-Book } & & & & -0.0103 & -0.0037 & -0.0099 \\
\hline & & & & $(0.0048)^{*}$ & $(0.0007)^{* *}$ & $(0.0054)$ \\
\hline \multirow[t]{2}{*}{ Tangibility } & & & & 0.0150 & 0.0933 & 0.0327 \\
\hline & & & & $(0.0230)$ & $(0.0466)^{*}$ & $(0.0374)$ \\
\hline \multirow[t]{2}{*}{ Profit } & & & & -0.6660 & -0.2251 & -0.8174 \\
\hline & & & & $(0.1137)^{* *}$ & $(0.0939)^{*}$ & $(0.1018)^{* *}$ \\
\hline Financial & & & & 0.0022 & 0.0018 & 0.0035 \\
\hline Constraint & & & & $(0.0018)$ & $(0.0014)$ & $(0.0018)^{*}$ \\
\hline \multirow[t]{2}{*}{ Stock Volatility } & & & & 0.4536 & 0.2302 & 0.4730 \\
\hline & & & & $(0.1142)^{* *}$ & $(0.1201)$ & $(0.1025)^{* *}$ \\
\hline County & & & & 0.0228 & 0.0453 & 0.0936 \\
\hline Religiosity & & & & $(0.0461)$ & $(0.0369)$ & $(0.0438)^{*}$ \\
\hline Catholic & & & & 0.0058 & 0.0079 & 0.0005 \\
\hline Proportion & & & & $(0.0057)$ & $(0.0053)$ & $(0.0062)$ \\
\hline \multirow[t]{2}{*}{ Per Capita Income } & & & & 0.0046 & 0.0842 & 0.0091 \\
\hline & & & & $(0.0294)$ & $(0.0274)^{* *}$ & $(0.0310)$ \\
\hline \multirow[t]{2}{*}{ Industry Debt/MVA } & & & & 0.3274 & & \\
\hline & & & & $(0.1858)$ & & \\
\hline Industry Debt/AT & & & & & $\begin{array}{c}0.1817 \\
(0.1365)\end{array}$ & \\
\hline \multirow[t]{2}{*}{ Industry TD/MVA } & & & & & & 0.4076 \\
\hline & & & & & & $(0.1796)^{*}$ \\
\hline \multirow[t]{2}{*}{ Constant } & -0.3257 & -0.2843 & -0.4155 & -0.3014 & -0.3116 & -0.7956 \\
\hline & $(0.0425)^{* *}$ & $(0.0764)^{* *}$ & $(0.0412)^{* *}$ & $(0.1236)^{*}$ & $(0.0994)^{* * *}$ & $(0.2780)^{* *}$ \\
\hline Adj. $R^{2}$ & 0.20 & 0.25 & 0.27 & 0.26 & 0.29 & 0.32 \\
\hline
\end{tabular}




\section{Table IV. Issuance and Religious Affiliation}

This table reports the relationship between debt and equity issuance and the Catholic religious affiliation of the CEO in the U.S. We use 2,406 firm-year observations from 1992-2010. Matched samples of Catholic and Protestant CEOs are used. Matching is performed on size, Fama-French (1992) 49 industries, and year. The financial constraint is the Kaplan and Zingales (1997) index. Other variables are as defined previously. Industry and year dummies are used, but not reported. Logit panel data regression methodology is used. Robust standard errors clustered by firm are reported in parentheses below the coefficients. * and ** represent statistical significance at $5 \%$ and $1 \%$ levels, respectively.

\begin{tabular}{|c|c|c|c|c|}
\hline & Debt Issue & Equity Issue & Debt Issue & Equity Issue \\
\hline & (1) & (2) & (3) & (4) \\
\hline \multirow[t]{2}{*}{ Catholic CEO } & -0.0638 & 0.0365 & -0.0414 & 0.0174 \\
\hline & $(0.0197)^{* *}$ & $(0.0138)^{* *}$ & $(0.0067)^{* *}$ & $(0.0045)^{* *}$ \\
\hline \multirow[t]{2}{*}{ Size } & 0.0976 & 0.2856 & 0.0346 & 0.3754 \\
\hline & $(0.0991)$ & $(0.2351)$ & $(0.0244)$ & $(0.2610)$ \\
\hline \multirow[t]{2}{*}{ Gender } & & & 0.5071 & 0.1081 \\
\hline & & & $(0.3562)$ & $(0.3912)$ \\
\hline \multirow[t]{2}{*}{ Age } & & & -0.0233 & -0.0379 \\
\hline & & & $(0.0075)^{* *}$ & $(0.0141)^{* *}$ \\
\hline \multirow[t]{2}{*}{ CEO Power } & & & -0.0765 & -0.0115 \\
\hline & & & $(0.1393)$ & $(0.2013)$ \\
\hline \multirow[t]{2}{*}{ Founder CEO } & & & -0.3060 & -0.1953 \\
\hline & & & $(0.3195)$ & $(0.4345)$ \\
\hline \multirow[t]{2}{*}{ Tenure } & & & 0.0092 & 0.0243 \\
\hline & & & $(0.0055)$ & $(0.0132)$ \\
\hline \multirow[t]{2}{*}{ Director } & & & 0.0323 & -0.2935 \\
\hline & & & $(0.2128)$ & $(0.2693)$ \\
\hline \multirow[t]{2}{*}{ Director $^{2}$} & & & -0.0013 & 0.0084 \\
\hline & & & $(0.0099)$ & $(0.0158)$ \\
\hline \multirow[t]{2}{*}{ Market-to-Book } & & & -0.0575 & 0.0410 \\
\hline & & & $(0.0260)^{*}$ & $(0.0223)$ \\
\hline \multirow[t]{2}{*}{ Tangibility } & & & 0.0060 & -0.2368 \\
\hline & & & $(0.0337)$ & $(0.2436)$ \\
\hline \multirow[t]{2}{*}{ Profit } & & & -0.1314 & 0.1938 \\
\hline & & & $(0.0373)^{* *}$ & $(0.4048)$ \\
\hline \multirow[t]{2}{*}{ Financial Constraint } & & & -0.0599 & 0.0958 \\
\hline & & & $(0.6569)$ & $(0.9371)$ \\
\hline \multirow[t]{2}{*}{ Stock Volatility } & & & 0.1806 & -0.9437 \\
\hline & & & $(0.4161)$ & $(4.5256)$ \\
\hline \multirow[t]{2}{*}{ County Religiosity } & & & -0.0683 & -0.1091 \\
\hline & & & $(0.4529)$ & $(0.7311)$ \\
\hline \multirow[t]{2}{*}{ Catholic Proportion } & & & 0.0676 & 0.0271 \\
\hline & & & $(0.0519)$ & $(0.0849)$ \\
\hline \multirow[t]{2}{*}{ Per Capita Income } & & & 0.0518 & -0.8663 \\
\hline & & & $(0.2298)$ & $(0.4223)^{*}$ \\
\hline \multirow[t]{2}{*}{ Constant } & -1.1315 & -0.9309 & -0.8788 & -1.6512 \\
\hline & $(0.2784)^{* *}$ & $(0.3034)^{* *}$ & $(2.6868)$ & $(4.5175)$ \\
\hline Pseudo $\mathrm{R}^{2}$ & 0.15 & 0.11 & 0.20 & 0.17 \\
\hline
\end{tabular}




\section{Table V. Diversification and Religious Affiliation}

This table reports the relationship between the different firm segments and the Catholic religious affiliation of the CEO in the U.S. We use 2,406 firm-year observations from 1992-2010. The variables are as defined previously. Robust standard errors clustered by firm are reported in parentheses below the coefficients. Industry and year dummies are used, but not reported. * and ** represent statistical significance at $5 \%$ and $1 \%$ levels, respectively.

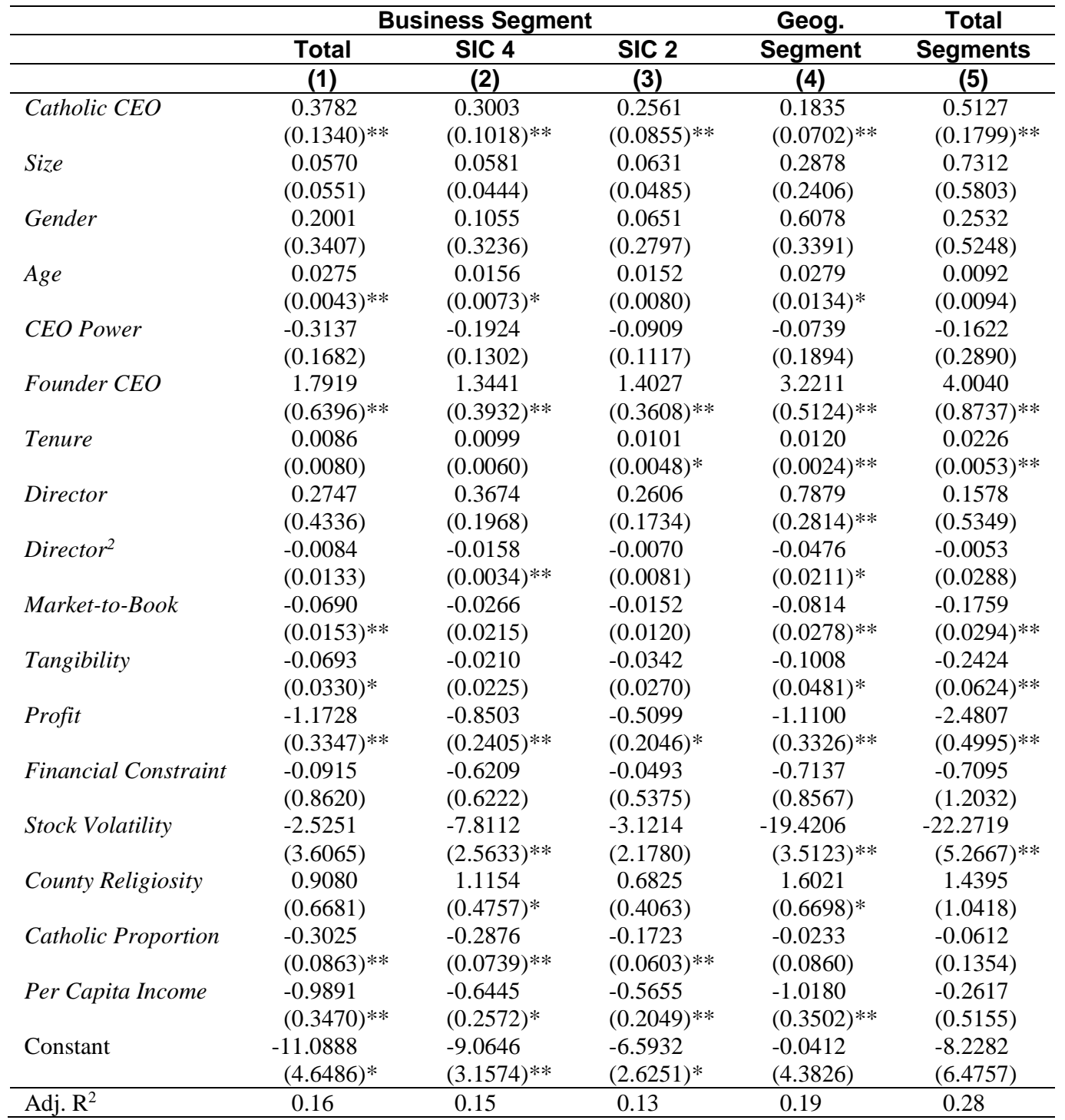




\section{Table VI. Investments and Religious Affiliation}

This table reports the relationship between investments and the Catholic religious affiliation of the CEO in the U.S. The data are for the years 1992-2010. We use 2,406 firm-year observations. Variables are as defined previously. Robust standard errors clustered by firm are reported in parentheses below the coefficients. Industry and year dummies are used, but not reported. * and ** represent statistical significance at $5 \%$ and $1 \%$ levels, respectively.

\begin{tabular}{|c|c|c|c|c|}
\hline & $\frac{\text { Cap Ex. }}{\text { (1) }}$ & $\frac{R \& D}{(2)}$ & $\frac{\text { Cap Ex. }}{(3)}$ & $\frac{\text { R\&D }}{(4)}$ \\
\hline Catholic CEO & $\begin{array}{l}-0.0065 \\
(0.0024) * *\end{array}$ & $\begin{array}{l}-0.0015 \\
(0.0004)^{* *}\end{array}$ & $\begin{array}{l}-0.0009 \\
(0.0002) * *\end{array}$ & $\begin{array}{l}-0.0032 \\
(0.0011)^{* *}\end{array}$ \\
\hline Size & $\begin{array}{l}-0.0048 \\
(0.0039)\end{array}$ & $\begin{array}{l}-0.0075 \\
(0.0046)\end{array}$ & $\begin{array}{l}-0.0026 \\
(0.0028)\end{array}$ & $\begin{array}{l}-0.0035 \\
(0.0035)\end{array}$ \\
\hline Gender & & & $\begin{array}{c}0.0396 \\
(0.0191)^{*}\end{array}$ & $\begin{array}{c}0.0500 \\
(0.0175)^{* *}\end{array}$ \\
\hline Age & & & $\begin{array}{l}-0.0005 \\
(0.0003)^{*}\end{array}$ & $\begin{array}{l}-0.0003 \\
(0.0003)\end{array}$ \\
\hline CEO Power & & & $\begin{array}{c}0.0020 \\
(0.0049)\end{array}$ & $\begin{array}{l}-0.0002 \\
(0.0045)\end{array}$ \\
\hline Founder CEO & & & $\begin{array}{c}0.0201 \\
(0.0134)\end{array}$ & $\begin{array}{l}-0.0339 \\
(0.0121)^{* *}\end{array}$ \\
\hline Tenure & & & $\begin{array}{c}0.0004 \\
(0.0002)\end{array}$ & $\begin{array}{l}-0.0005 \\
(0.0002)^{*}\end{array}$ \\
\hline Director & & & $\begin{array}{c}0.0049 \\
(0.0072)\end{array}$ & $\begin{array}{c}0.0084 \\
(0.0087)\end{array}$ \\
\hline Director $^{2}$ & & & $\begin{array}{l}-0.0002 \\
(0.0003)\end{array}$ & $\begin{array}{l}-0.0004 \\
(0.0003)\end{array}$ \\
\hline Market-to-Book & & & $\begin{array}{l}0.0013 \\
(0.0004)^{* *}\end{array}$ & $\begin{array}{c}0.0025 \\
(0.0012)^{*}\end{array}$ \\
\hline Tangibility & & & $\begin{array}{c}0.0040 \\
(0.0026)\end{array}$ & $\begin{array}{l}0.0085 \\
(0.0017)^{* *}\end{array}$ \\
\hline Profit & & & $\begin{array}{c}0.1446 \\
(0.0128)^{* *}\end{array}$ & $\begin{array}{c}0.0193 \\
(0.0083)^{*}\end{array}$ \\
\hline Financial Constraint & & & $\begin{array}{l}-0.1013 \\
(0.0429)^{*}\end{array}$ & $\begin{array}{l}-0.1144 \\
(0.0574)^{*}\end{array}$ \\
\hline Stock Volatility & & & $\begin{array}{c}0.4081 \\
(0.0961)^{* * *}\end{array}$ & $\begin{array}{c}0.1394 \\
(0.0847)\end{array}$ \\
\hline County Religiosity & & & $\begin{array}{c}0.0129 \\
(0.0138)\end{array}$ & $\begin{array}{c}0.0316 \\
(0.0119)^{* *}\end{array}$ \\
\hline Catholic Proportion & & & $\begin{array}{c}0.0026 \\
(0.0035)\end{array}$ & $\begin{array}{l}0.0108 \\
(0.0027)^{* *}\end{array}$ \\
\hline Per Capita Income & & & $\begin{array}{c}0.0011 \\
(0.0084)\end{array}$ & $\begin{array}{c}0.0027 \\
(0.0134)\end{array}$ \\
\hline Constant & $\begin{array}{l}0.0702 \\
(0.0087)^{* *}\end{array}$ & $\begin{array}{l}0.0936 \\
(0.0137)^{* *}\end{array}$ & $\begin{array}{c}0.1945 \\
(0.1167) \\
\end{array}$ & $\begin{array}{c}0.2747 \\
(0.1269)^{*} \\
\end{array}$ \\
\hline Adj. $\mathrm{R}^{2}$ & 0.23 & 0.16 & 0.38 & 0.29 \\
\hline
\end{tabular}




\section{Table VII. CEO's Religious Affiliation and Shareholdings}

This table reports the relationship between pay and the Catholic religious affiliation of the CEO in the U.S. We use 2,406 firm-year observations from 1992-2010. The variables are as defined previously. Industry and year dummies are used, but not reported. Robust standard errors clustered by firm are reported in parentheses below the coefficients. * and ** represent statistical significance at $5 \%$ and $1 \%$ levels, respectively.

\begin{tabular}{|c|c|c|c|c|}
\hline & Own & Trading & Own & Trading \\
\hline & $(1)$ & (2) & (3) & (4) \\
\hline \multirow[t]{2}{*}{ Catholic CEO } & -0.0154 & -0.0026 & -0.0067 & -0.0028 \\
\hline & $(0.0044)^{* *}$ & $(0.0006)^{* *}$ & $(0.0016) * *$ & $(0.0008) * *$ \\
\hline \multirow[t]{2}{*}{ Size } & -0.0066 & -0.0005 & -0.0033 & -0.0008 \\
\hline & $(0.0048)$ & $(0.0004)$ & $(0.0029)$ & $(0.0005)$ \\
\hline \multirow[t]{2}{*}{ Gender } & & & 0.0157 & 0.0010 \\
\hline & & & $(0.0101)$ & $(0.0008)$ \\
\hline \multirow[t]{2}{*}{ Age } & & & 0.0005 & 0.0003 \\
\hline & & & $(0.0006)$ & $(0.0001)^{* *}$ \\
\hline \multirow[t]{2}{*}{ CEO Power } & & & 0.0173 & 0.0004 \\
\hline & & & $(0.0087)^{*}$ & $(0.0047)$ \\
\hline \multirow[t]{2}{*}{ Founder CEO } & & & 0.0444 & 0.0004 \\
\hline & & & $(0.0267)$ & $(0.0092)$ \\
\hline \multirow[t]{2}{*}{ Tenure } & & & 0.0008 & 0.0001 \\
\hline & & & $(0.0005)$ & $(0.0001)$ \\
\hline \multirow[t]{2}{*}{ Director } & & & 0.0769 & 0.0004 \\
\hline & & & $(0.0153)^{* *}$ & $(0.0011)$ \\
\hline \multirow[t]{2}{*}{ Director $^{2}$} & & & -0.0042 & -0.0001 \\
\hline & & & $(0.0008)^{* *}$ & $(0.0001)$ \\
\hline \multirow[t]{2}{*}{ Market-to-Book } & & & 0.0009 & 0.0001 \\
\hline & & & $(0.0002)^{* *}$ & $(0.0004)$ \\
\hline \multirow[t]{2}{*}{ Tangibility } & & & -0.0470 & -0.0024 \\
\hline & & & $(0.0227)^{*}$ & $(0.0010)^{*}$ \\
\hline \multirow[t]{2}{*}{ Profit } & & & -0.0331 & -0.0180 \\
\hline & & & $(0.0432)$ & $(0.0037)^{* *}$ \\
\hline \multirow[t]{2}{*}{ Financial Constraint } & & & -0.0020 & -0.0001 \\
\hline & & & $(0.0005)^{* *}$ & $(0.0001)$ \\
\hline \multirow[t]{2}{*}{ Stock Volatility } & & & 0.3945 & 0.0292 \\
\hline & & & $(0.2563)$ & $(0.0211)$ \\
\hline \multirow[t]{2}{*}{ County Religiosity } & & & -0.0692 & -0.0009 \\
\hline & & & $(0.0501)$ & $(0.0027)$ \\
\hline \multirow[t]{2}{*}{ Catholic Proportion } & & & 0.0091 & 0.0009 \\
\hline & & & $(0.0043)^{*}$ & $(0.0005)$ \\
\hline \multirow[t]{2}{*}{ Per Capita Income } & & & 0.0788 & 0.0012 \\
\hline & & & $(0.0206)^{* *}$ & $(0.0013)$ \\
\hline \multirow[t]{2}{*}{ Constant } & 0.0360 & 0.0154 & 0.2351 & 0.0047 \\
\hline & $(0.0087)^{* *}$ & $(0.0016)^{* *}$ & $(0.2109)$ & $(0.0205)$ \\
\hline Adj. $R^{2}$ & 0.15 & 0.08 & 0.23 & 0.11 \\
\hline
\end{tabular}


Table VIII. Firm Value and CEO's Religious Affiliations

This table reports the relationship between free cash flows and the religious affiliations of the CEO. The odd numbered columns use Profit (operating cash flows scaled by total assets) as the dependent variable, while the even numbered column uses Q (or Tobin's Q) as the dependent variable. $\Delta$ refers to the first difference. Segments in the independent variables column refer to Business Segments total. The rest of the variables are as defined previously. Year and Fama-French (1992) 49 industry dummies are used, but not reported. Robust standard errors clustered by firm are reported in parentheses below the coefficients. * and ** represent statistical significance at $5 \%$ and $1 \%$ levels, respectively.

\begin{tabular}{|c|c|c|c|c|}
\hline \multicolumn{5}{|c|}{ Panel A. Effect of Changes in Leverage and Segments } \\
\hline & Profit & $\mathbf{Q}$ & Profit & $\mathbf{Q}$ \\
\hline & $(1)$ & $(2)$ & (3) & $(4)$ \\
\hline \multirow[t]{2}{*}{ Catholic CEO } & -0.0155 & -0.0086 & -0.0240 & -0.0063 \\
\hline & $(0.0071)^{*}$ & $(0.0169)$ & $(0.0024)^{* *}$ & $(0.0043)$ \\
\hline \multirow[t]{2}{*}{ Catholic CEO *A Debt/MVA } & 0.5103 & 0.1549 & & \\
\hline & $(0.0703)^{* *}$ & $(0.0230)^{* *}$ & & \\
\hline \multirow[t]{2}{*}{$\triangle \mathrm{Debt} / \mathrm{MVA}$} & -0.3611 & -0.0412 & & \\
\hline & $(0.1278)^{* *}$ & $(0.0525)$ & & \\
\hline \multirow[t]{2}{*}{ Catholic CEO * $\triangle$ Segments } & & & -0.0291 & -0.0096 \\
\hline & & & $(0.0030)^{* *}$ & $(0.0034) * *$ \\
\hline \multirow{2}{*}{$\Delta$ Segments } & & & 0.0110 & 0.0061 \\
\hline & & & $(0.0065)$ & $(0.0011)^{* *}$ \\
\hline \multirow[t]{2}{*}{ Size } & -0.0032 & -0.0008 & -0.0029 & -0.0087 \\
\hline & $(0.0028)$ & $(0.0024)$ & $(0.0025)$ & $(0.0030)^{* *}$ \\
\hline \multirow[t]{2}{*}{ Gender } & -0.0318 & -0.0137 & -0.0721 & -0.0015 \\
\hline & $(0.0053)^{* *}$ & $(0.0236)$ & $(0.0367)^{*}$ & $(0.0022)$ \\
\hline \multirow[t]{2}{*}{ Age } & -0.0006 & -0.0015 & -0.0005 & -0.0006 \\
\hline & $(0.0004)$ & $(0.0003)^{* *}$ & $(0.0005)$ & $(0.0006)$ \\
\hline \multirow[t]{2}{*}{ CEO Power } & -0.0098 & 0.0019 & 0.0108 & -0.0185 \\
\hline & $(0.0086)$ & $(0.0060)$ & $(0.0076)$ & $(0.0088)^{*}$ \\
\hline \multirow[t]{2}{*}{ Founder CEO } & 0.0476 & -0.0155 & 0.0113 & 0.0639 \\
\hline & $(0.0195)$ & $(0.0149)$ & $(0.0203)$ & $(0.0201)^{* *}$ \\
\hline \multirow[t]{2}{*}{ Tenure } & -0.0001 & -0.0001 & -0.0003 & -0.0009 \\
\hline & $(0.0003)$ & $(0.0003)$ & $(0.0004)$ & $(0.0005)$ \\
\hline \multirow[t]{2}{*}{ Director } & 0.0065 & 0.0094 & 0.0045 & 0.0058 \\
\hline & $(0.0079)$ & $(0.0170)$ & $(0.0096)$ & $(0.0238)$ \\
\hline \multirow[t]{2}{*}{ Director $^{2}$} & -0.0003 & -0.0005 & -0.0002 & -0.0005 \\
\hline & $(0.0006)$ & $(0.0009)$ & $(0.0007)$ & $(0.0007)$ \\
\hline \multirow[t]{2}{*}{ Tangibility } & 0.0005 & 0.0046 & 0.0048 & 0.0028 \\
\hline & $(0.0102)$ & $(0.0068)$ & $(0.0070)$ & $(0.0197)$ \\
\hline \multirow[t]{2}{*}{ Financial Constraint } & -0.0004 & -0.0027 & -0.0007 & -0.0004 \\
\hline & $(0.0007)$ & $(0.0009)^{* *}$ & $(0.0007)$ & $(0.0006)$ \\
\hline \multirow[t]{2}{*}{ Stock Volatility } & 0.1812 & 0.1682 & 0.3816 & 0.3651 \\
\hline & $(0.0620)^{* *}$ & $(0.0724)^{*}$ & $(0.0786)^{* *}$ & $(0.0750)^{* *}$ \\
\hline \multirow[t]{2}{*}{ County Religiosity } & 0.0163 & 0.0136 & 0.0883 & 0.1506 \\
\hline & $(0.0438)$ & $(0.0361)$ & $(0.0364)^{*}$ & $(0.0274)^{* *}$ \\
\hline \multirow[t]{2}{*}{ Catholic Proportion } & 0.0209 & 0.0022 & 0.0071 & 0.0131 \\
\hline & $(0.0045)^{* *}$ & $(0.0026)$ & $(0.0054)$ & $(0.0054)^{*}$ \\
\hline \multirow[t]{2}{*}{ Per Capita Income } & 0.0332 & 0.0074 & 0.0004 & 0.0405 \\
\hline & $(0.0049)^{* *}$ & $(0.0041)$ & $(0.0291)$ & $(0.0069)^{* *}$ \\
\hline \multirow[t]{2}{*}{ Constant } & 0.9953 & 0.6675 & 1.0285 & 0.5217 \\
\hline & $(0.2060)^{* * *}$ & $(0.1676)^{* *}$ & $(0.2021) * *$ & $(0.1232)^{* *}$ \\
\hline Adj. $\mathrm{R}^{2}$ & 0.15 & 0.15 & 0.16 & 0.19 \\
\hline
\end{tabular}




\begin{tabular}{|c|c|c|c|c|}
\hline \multicolumn{5}{|c|}{ Panel B. Effect of Changes in Capital Expenditures and CEO's Stock Ownership } \\
\hline & Profit & $\mathbf{Q}$ & Profit & $\mathbf{Q}$ \\
\hline & (5) & (6) & (7) & (8) \\
\hline \multirow[t]{2}{*}{ Catholic CEO } & -0.0149 & -0.0133 & -0.0069 & -0.0097 \\
\hline & $(0.0331)$ & $(0.0123)$ & $(0.0273)$ & $(0.0078)$ \\
\hline \multirow[t]{2}{*}{ Catholic CEO * $\triangle$ Cap Ex } & 0.7841 & 0.4248 & & \\
\hline & $(0.2638)^{* *}$ & $(0.0954)^{* *}$ & & \\
\hline \multirow[t]{2}{*}{$\triangle$ Cap Ex. } & 0.2513 & 0.2283 & & \\
\hline & $(1.0979)$ & $(0.1908)$ & & \\
\hline \multirow[t]{2}{*}{ Catholic CEO * O Own } & & & 0.3234 & 0.0867 \\
\hline & & & $(0.1057)^{* *}$ & $(0.0324) * *$ \\
\hline \multirow[t]{2}{*}{$\Delta O w n$} & & & 0.5114 & 0.0667 \\
\hline & & & $(0.8998)$ & $(0.0905)$ \\
\hline \multirow[t]{2}{*}{ Size } & -0.0008 & -0.0005 & -0.0050 & -0.0014 \\
\hline & $(0.0042)$ & $(0.0050)$ & $(0.0040)$ & $(0.0029)$ \\
\hline \multirow[t]{2}{*}{ Gender } & -0.0293 & -0.0267 & -0.0068 & -0.0254 \\
\hline & $(0.0102)^{* *}$ & $(0.0412)$ & $(0.0122)$ & $(0.0123)^{*}$ \\
\hline \multirow[t]{2}{*}{ Age } & -0.0005 & -0.0006 & -0.0010 & -0.0001 \\
\hline & $(0.0011)$ & $(0.0006)$ & $(0.0011)$ & $(0.0005)$ \\
\hline \multirow[t]{2}{*}{ CEO Power } & -0.0008 & 0.0052 & 0.0009 & -0.0145 \\
\hline & $(0.0123)$ & $(0.0094)$ & $(0.0118)$ & $(0.0108)$ \\
\hline \multirow[t]{2}{*}{ Founder CEO } & -0.0026 & 0.0099 & -0.0164 & 0.0626 \\
\hline & $(0.0292)$ & $(0.0275)$ & $(0.0418)$ & $(0.0175)^{* *}$ \\
\hline \multirow[t]{2}{*}{ Tenure } & -0.0003 & -0.0003 & -0.0010 & -0.0006 \\
\hline & $(0.0007)$ & $(0.0006)$ & $(0.0010)$ & $(0.0003)$ \\
\hline \multirow[t]{2}{*}{ Director } & 0.0058 & 0.0019 & 0.0071 & 0.0084 \\
\hline & $(0.0157)$ & $(0.0019)$ & $(0.0115)$ & $(0.0160)$ \\
\hline \multirow[t]{2}{*}{ Director $^{2}$} & -0.0010 & -0.0001 & -0.0004 & -0.0006 \\
\hline & $(0.0009)$ & $(0.0005)$ & $(0.0007)$ & $(0.0006)$ \\
\hline \multirow[t]{2}{*}{ Tangibility } & 0.0867 & 0.0988 & 0.0061 & 0.0055 \\
\hline & $(0.0368)^{*}$ & $(0.0386)^{*}$ & $(0.0236)$ & $(0.0222)$ \\
\hline \multirow[t]{2}{*}{ Financial Constraint } & -0.0009 & -0.0065 & -0.0005 & -0.0018 \\
\hline & $(0.0008)$ & $(0.0048)$ & $(0.0009)$ & $(0.0010)$ \\
\hline \multirow[t]{2}{*}{ Stock Volatility } & 0.3774 & 0.4798 & 0.5783 & 0.2401 \\
\hline & $(0.1536)^{*}$ & $(0.1183)^{* *}$ & $(0.1828)^{* *}$ & $(0.0668)^{* *}$ \\
\hline \multirow[t]{2}{*}{ County Religiosity } & 0.0630 & 0.0028 & 0.0247 & 0.0057 \\
\hline & $(0.0572)$ & $(0.0680)$ & $(0.0611)$ & $(0.0242)$ \\
\hline \multirow[t]{2}{*}{ Catholic Proportion } & 0.0001 & 0.0059 & 0.0014 & 0.0050 \\
\hline & $(0.0086)$ & $(0.0056)$ & $(0.0086)$ & $(0.0048)$ \\
\hline \multirow[t]{2}{*}{ Per Capita Income } & 0.0074 & 0.0375 & 0.0267 & 0.0570 \\
\hline & $(0.0367)$ & $(0.0400)$ & $(0.0451)$ & $(0.0122)^{* *}$ \\
\hline \multirow[t]{2}{*}{ Constant } & 0.5941 & 0.4621 & 0.2881 & 0.4579 \\
\hline & $(0.4018)$ & $(0.3430)$ & $(0.4959)$ & $(0.2004)^{*}$ \\
\hline Adj. $\mathrm{R}^{2}$ & 0.16 & 0.13 & 0.20 & 0.20 \\
\hline
\end{tabular}




\section{Table IX. Change in CEO and Corporate Decisions}

This table reports the relationship between the differences $(\Delta)$ of the various dependent variables and the religious affiliations of the CEOs. These differences are calculated by taking the differences in the values of the variables one year after a CEO change and one year prior to a CEO change. We use 390 observations. The variables are as defined previously. Year and Fama-French (1992) 49 industry dummies are used, but not reported. The table uses OLS regression methodology. Robust standard errors are reported in parentheses below the coefficients. * and ** represent statistical significance at $5 \%$ and $1 \%$ levels, respectively.

\begin{tabular}{|c|c|c|c|c|}
\hline \multicolumn{5}{|c|}{ Panel A. Change of CEO from Protestant to Catholics and CEOs from the Same Religion } \\
\hline & $\Delta$ Debt/MVA & $\Delta$ Business Segment & $\Delta$ Cap Ex. & $\Delta$ Own \\
\hline \multicolumn{5}{|c|}{ Total } \\
\hline & (1) & $(2)$ & (3) & $(4)$ \\
\hline \multirow[t]{2}{*}{$\triangle$ Catholic CEO } & -0.0329 & 0.0466 & -0.0045 & -0.0066 \\
\hline & $(0.0088)^{* *}$ & $(0.0110)^{* *}$ & $(0.0015)^{* *}$ & $(0.0023)^{* *}$ \\
\hline \multirow[t]{2}{*}{ Size } & 0.0396 & 0.1883 & -0.0037 & -0.0141 \\
\hline & $(0.0061)^{* *}$ & $(0.0611)^{* *}$ & $(0.0009)^{* *}$ & $(0.0017)^{* *}$ \\
\hline \multirow[t]{2}{*}{ Gender } & -0.0367 & 0.6142 & 0.0022 & 0.0245 \\
\hline & $(0.0626)$ & $(0.6198)$ & $(0.0084)$ & $(0.0285)$ \\
\hline \multirow[t]{2}{*}{ Age } & 0.0011 & 0.0247 & -0.0006 & 0.0001 \\
\hline & $(0.0012)$ & $(0.0224)$ & $(0.0002)^{* *}$ & $(0.0006)$ \\
\hline \multirow[t]{2}{*}{ CEO Power } & 0.0151 & -0.0891 & -0.0029 & 0.0310 \\
\hline & $(0.0195)$ & $(0.2619)$ & $(0.0039)$ & $(0.0111)^{* *}$ \\
\hline \multirow[t]{2}{*}{ Founder $C E O$} & -0.0516 & -0.2076 & 0.0281 & 0.0297 \\
\hline & $(0.0468)$ & $(0.6112)$ & $(0.0072)$ & $(0.0284)$ \\
\hline \multirow[t]{2}{*}{ Tenure } & 0.0005 & 0.0223 & 0.0001 & 0.0029 \\
\hline & $(0.0021)$ & $(0.0184)$ & $(0.0002)$ & $(0.0006)^{* *}$ \\
\hline \multirow[t]{2}{*}{ Director } & 0.0610 & 0.2592 & 0.0010 & 0.0334 \\
\hline & $(0.0242)^{*}$ & $(0.2771)$ & $(0.0066)$ & $(0.0077)^{* *}$ \\
\hline \multirow[t]{2}{*}{ Director $^{2}$} & -0.0022 & -0.0246 & -0.0001 & -0.0009 \\
\hline & $(0.0009)^{*}$ & $(0.0064)^{* *}$ & $(0.0004)$ & $(0.0005)$ \\
\hline \multirow[t]{2}{*}{ Market-to-Book } & -0.0262 & -0.0003 & 0.0054 & 0.0010 \\
\hline & $(0.0040)^{* *}$ & $(0.0474)$ & $(0.0016)^{* *}$ & $(0.0013)$ \\
\hline \multirow[t]{2}{*}{ Tangibility } & 0.0651 & -1.6855 & 0.1721 & 0.0243 \\
\hline & $(0.0368)$ & $(0.5208)^{* *}$ & $(0.0098)^{* *}$ & $(0.0278)$ \\
\hline \multirow[t]{2}{*}{ Profit } & -0.6081 & -0.5176 & 0.0446 & -0.0187 \\
\hline & $(0.0687)^{* *}$ & $(0.9738)$ & $(0.0216)^{*}$ & $(0.0188)$ \\
\hline \multirow[t]{2}{*}{ Financial Constraint } & -0.0035 & -0.0462 & -0.0009 & 0.0004 \\
\hline & $(0.0009)^{* *}$ & $(0.0140)^{* *}$ & $(0.0003)^{*}$ & $(0.0003)$ \\
\hline \multirow[t]{2}{*}{ Stock Volatility } & 0.4426 & -0.5250 & 0.1090 & 0.1058 \\
\hline & $(0.1042)^{* *}$ & $(1.5308)$ & $(0.0292)^{* *}$ & $(0.0425)^{*}$ \\
\hline \multirow[t]{2}{*}{ County Religiosity } & 0.1703 & -1.1715 & -0.0453 & 0.0411 \\
\hline & $(0.0799)^{*}$ & $(1.1151)$ & $(0.0197)^{*}$ & $(0.0357)$ \\
\hline \multirow[t]{2}{*}{ Catholic Proportion } & 0.0066 & 0.1457 & 0.0100 & -0.0084 \\
\hline & $(0.0054)$ & $(0.1576)$ & $(0.0028)^{* *}$ & $(0.0055)$ \\
\hline \multirow[t]{2}{*}{ Per Capita Income } & -0.1219 & -1.1060 & 0.0038 & 0.0037 \\
\hline & $(0.0483)^{*}$ & $(0.6213)$ & $(0.0100)$ & $(0.0329)$ \\
\hline \multirow[t]{2}{*}{ Constant } & 1.6006 & 13.6291 & -0.1263 & 0.3083 \\
\hline & $(0.5342)^{* *}$ & $(6.6305)^{*}$ & $(0.1313)$ & $(0.2837)$ \\
\hline Adj. $\mathrm{R}^{2}$ & 0.09 & 0.06 & 0.08 & 0.11 \\
\hline
\end{tabular}




\begin{tabular}{|c|c|c|c|c|}
\hline \multicolumn{5}{|c|}{ Panel B. Change of CEO from Catholic to Protestant and CEOs from the Same Religion } \\
\hline & $\Delta$ Debt/MVA & $\Delta$ Business Segment & $\Delta$ Cap Ex. & $\Delta$ Own \\
\hline \multicolumn{5}{|c|}{ Total } \\
\hline & (1) & $(2)$ & (3) & $(4)$ \\
\hline \multirow[t]{2}{*}{$\triangle$ Catholic CEO } & 0.0079 & -0.3269 & 0.0003 & 0.0103 \\
\hline & $(0.0035)^{*}$ & $(0.1122)^{* *}$ & $(0.0001)^{* *}$ & $(0.0043)^{*}$ \\
\hline \multirow[t]{2}{*}{ Size } & 0.0427 & 0.2072 & -0.0081 & -0.0082 \\
\hline & $(0.0055)^{* *}$ & $(0.0744)^{* *}$ & $(0.0005)^{* *}$ & $(0.0016)^{* *}$ \\
\hline \multirow[t]{2}{*}{ Gender } & 0.1091 & -0.6658 & 0.0046 & 0.0042 \\
\hline & $(0.0632)$ & $(0.6296)$ & $(0.0082)$ & $(0.0298)$ \\
\hline \multirow[t]{2}{*}{ Age } & 0.0009 & 0.0007 & -0.0002 & 0.0003 \\
\hline & $(0.0015)$ & $(0.0202)$ & $(0.0002)$ & $(0.0006)$ \\
\hline \multirow[t]{2}{*}{ CEO Power } & 0.0250 & -0.0675 & -0.0101 & 0.0263 \\
\hline & $(0.0187)$ & $(0.2322)$ & $(0.0051)^{*}$ & $(0.0095)^{* *}$ \\
\hline \multirow[t]{2}{*}{ Founder CEO } & -0.0740 & -0.2052 & 0.0321 & 0.0519 \\
\hline & $(0.0528)$ & $(0.5969)$ & $(0.0101)^{* *}$ & $(0.0347)$ \\
\hline \multirow[t]{2}{*}{ Tenure } & 0.0005 & 0.0142 & 0.0006 & 0.0005 \\
\hline & $(0.0009)$ & $(0.0158)$ & $(0.0001)^{* *}$ & $(0.0004)$ \\
\hline \multirow[t]{2}{*}{ Director } & 0.0124 & -0.4344 & 0.0206 & -0.0310 \\
\hline & $(0.0225)$ & $(0.3425)$ & $(0.0097)^{*}$ & $(0.0097)^{* *}$ \\
\hline \multirow[t]{2}{*}{ Director $^{2}$} & -0.0008 & -0.0325 & -0.0007 & -0.0011 \\
\hline & $(0.0020)$ & $(0.0112)^{* *}$ & $(0.0006)$ & $(0.0005)^{*}$ \\
\hline \multirow[t]{2}{*}{ Market-to-Book } & -0.0180 & -0.0050 & 0.0050 & 0.0022 \\
\hline & $(0.0026)^{* *}$ & $(0.0491)$ & $(0.0010)^{* *}$ & $(0.0018)$ \\
\hline \multirow[t]{2}{*}{ Tangibility } & 0.0636 & -1.3445 & 0.1866 & -0.0001 \\
\hline & $(0.0372)$ & $(0.4389)^{* *}$ & $(0.0097)^{* *}$ & $(0.0078)$ \\
\hline \multirow[t]{2}{*}{ Profit } & -0.5639 & -0.1488 & 0.0862 & -0.0280 \\
\hline & $(0.0700)^{* *}$ & $(0.9563)$ & $(0.0361)^{*}$ & $(0.0199)$ \\
\hline \multirow[t]{2}{*}{ Financial Constraint } & -0.0024 & -0.0194 & -0.0007 & 0.0004 \\
\hline & $(0.0018)$ & $(0.0080)^{*}$ & $(0.0004)^{*}$ & $(0.0003)$ \\
\hline \multirow[t]{2}{*}{ Stock Volatility } & 0.6772 & -2.0450 & 0.0668 & 0.0467 \\
\hline & $(0.1044)^{* *}$ & $(1.3703)$ & $(0.0414)$ & $(0.0360)$ \\
\hline \multirow[t]{2}{*}{ County Religiosity } & -0.0441 & 0.2599 & 0.0123 & -0.0253 \\
\hline & $(0.0756)$ & $(0.8316)$ & $(0.0113)$ & $(0.0224)$ \\
\hline \multirow[t]{2}{*}{ Catholic Proportion } & 0.0103 & 0.1145 & -0.0001 & -0.0061 \\
\hline & $(0.0129)$ & $(0.1322)$ & $(0.0028)$ & $(0.0057)$ \\
\hline \multirow[t]{2}{*}{ Per Capita Income } & -0.1364 & -1.7694 & 0.0023 & 0.0070 \\
\hline & $(0.0401)^{* *}$ & $(0.5721)^{* *}$ & $(0.0085)$ & $(0.0326)$ \\
\hline \multirow[t]{2}{*}{ Constant } & 1.8547 & 20.0062 & -0.2288 & 0.4089 \\
\hline & $(0.5283)^{* *}$ & $(6.1519)^{* *}$ & $(0.1370)$ & $(0.3180)$ \\
\hline Adj. $\mathrm{R}^{2}$ & 0.12 & 0.05 & 0.09 & 0.10 \\
\hline
\end{tabular}




\section{Table X. Robustness from International Data}

\section{Panel A. Summary Statistics of International Data}

The Uncertainty Avoidance Index is a measure of a society's tolerance for uncertainty and ambiguity obtained from Hofstede (2001). GDP is the average of the PPP adjusted GDP per capita from 1980-2008. Corrupt is the average corruption score from 1996-2000. Privo is the ratio of private credit to GDP averaged from 1999-2003. UK Origin is the British legal origin of the countries. $* * *$, and $* * *$ represent statistical significance at $10 \%, 5 \%$, and $1 \%$ levels, respectively.

\begin{tabular}{lcccc}
\hline \multicolumn{1}{c}{ Variable } & Combined & Protestant Countries & Catholic Countries & (3) - (2) \\
\hline Uncertainty & $\mathbf{( 1 )}$ & $\mathbf{( 2 )}$ & $\mathbf{( 3 )}$ & \\
Avoidance Index & 67.6410 & 60.7143 & 79.3448 & $18.6305^{* * *}$ \\
GDP & 9.3155 & 9.2667 & 9.3813 & 0.1146 \\
Corrupt & 0.6292 & 0.7661 & 0.4497 & -0.3164 \\
Privo & 0.6643 & 0.7503 & 0.5486 & $-0.2017^{*}$ \\
UK Origin & 0.2319 & 0.3500 & 0.0690 & $-0.2810^{* * *}$ \\
\hline
\end{tabular}

Panel B. All Countries

The dependent variable is the Uncertainty Avoidance Index (UAI) as defined by Geert Hofstede (2001). The other cultural norms defined by Hofstede (2001) include PDI (the Power Distance Index), IDV (individualism vs. collectivism), MAS (masculinity vs. femininity), and PRA (pragmatic vs. normative). Catholic Country is a dummy variable if the majority of the population in a country adheres to the Catholic denomination. \%Catholic is the percentage of the population who are Catholics. Similarly, $\%$ Protestant is the percentage of the population who are Protestants. GDP is the average of the PPP adjusted GDP per capita from 1980-2008. Corrupt is the average corruption score from 1996-2000. Privo is the ratio of private credit to GDP averaged from 1999-2003. UK Origin is the British legal origin of the countries. We employ OLS regressions with robust standard errors. * and ** represent statistical significance at $5 \%$ and $1 \%$ levels, respectively.

\begin{tabular}{|c|c|c|c|c|c|c|}
\hline & (1) & (2) & (3) & (4) & (5) & (6) \\
\hline \multirow{2}{*}{$\begin{array}{l}\text { Catholic } \\
\text { Country }\end{array}$} & 18.6305 & & & 11.9330 & & \\
\hline & $(4.5867)^{* *}$ & & & $(5.1032)^{*}$ & & \\
\hline$\%$ Catholic & & $\begin{array}{l}0.3072 \\
(0.0813)^{* *}\end{array}$ & & & $\begin{array}{c}0.1849 \\
(0.0889)^{*}\end{array}$ & \\
\hline$\%$ Protestant & & & $\begin{array}{l}-0.4201 \\
(0.1017)^{* *}\end{array}$ & & & $\begin{array}{l}-0.4056 \\
(0.1340)^{* *}\end{array}$ \\
\hline$G D P$ & & & & $\begin{array}{c}9.3502 \\
(5.3899)\end{array}$ & $\begin{array}{c}8.8499 \\
(6.0771)\end{array}$ & $\begin{array}{l}10.4364 \\
(5.2917)\end{array}$ \\
\hline Corrupt & & & & $\begin{array}{l}-9.6712 \\
(4.0535)^{*}\end{array}$ & $\begin{array}{l}-8.9456 \\
(4.9061)\end{array}$ & $\begin{array}{l}-1.9202 \\
(4.9758)\end{array}$ \\
\hline Privo & & & & $\begin{array}{l}-2.7406 \\
(7.0289)\end{array}$ & $\begin{array}{l}-5.3614 \\
(7.2863)\end{array}$ & $\begin{array}{r}-11.4869 \\
(8.6756)\end{array}$ \\
\hline UK Origin & & & & $\begin{array}{c}-17.9687 \\
(7.2604)^{*}\end{array}$ & $\begin{array}{l}-18.4692 \\
(7.7004)^{*}\end{array}$ & $\begin{array}{r}-18.5377 \\
(6.7319)^{* *}\end{array}$ \\
\hline Constant & $\begin{array}{l}60.7143 \\
(3.3585) * *\end{array}$ & $\begin{array}{l}53.2428 \\
(5.6084) * *\end{array}$ & $\begin{array}{l}75.7774 \\
(3.8046)^{* *}\end{array}$ & $\begin{array}{l}-13.2143 \\
(47.3881)\end{array}$ & $\begin{array}{l}-11.0101 \\
(53.1279)\end{array}$ & $\begin{array}{c}-9.6445 \\
(48.3082)\end{array}$ \\
\hline Observations & 78 & 59 & 55 & 66 & 57 & 54 \\
\hline R-squared & 0.16 & 0.23 & 0.20 & 0.43 & 0.46 & 0.48 \\
\hline
\end{tabular}


Panel C. Christian-Majority Countries

Dependent Variable: Uncertainty Avoidance Index (UAI), as defined by Geert Hofstede (2001). The other cultural norms defined by Hofstede (2001) are PDI (the power distance index), IDV (individualism vs. collectivism), MAS (masculinity vs. femininity), and PRA (pragmatic vs. normative). Catholic Country is a dummy variable if the majority of the population in a country adheres to the Catholic denomination. \%Catholic is the percentage of the population who are Catholics. Similarly, \%Protestant is the percentage of the population who are Protestants. GDP is the average of the PPP adjusted GDP per capita from 1980-2008. Corrupt is the average corruption score from 1996-2000. Privo is the ratio of private credit to GDP averaged from 1999-2003. UK Origin is the British legal origin of the countries. We employ OLS regressions with robust standard errors. * and ** represent statistical significance at $5 \%$ and $1 \%$ levels, respectively.

\begin{tabular}{|c|c|c|c|c|c|c|}
\hline & (1) & (2) & (3) & (4) & (5) & (6) \\
\hline Catholic & 21.4448 & & & 11.8737 & & \\
\hline & $(6.3064)^{* *}$ & & & $(5.6004)^{*}$ & & \\
\hline$\%$ Catholic & & $\begin{array}{c}0.2805 \\
(0.1065)^{*}\end{array}$ & & & $\begin{array}{c}0.1547 \\
(0.0906)^{*}\end{array}$ & \\
\hline$\%$ Protestant & & & $\begin{array}{l}-0.5498 \\
(0.1015)^{* *}\end{array}$ & & & $\begin{array}{l}-0.4265 \\
(0.1265)^{* *}\end{array}$ \\
\hline$G D P$ & & & & $\begin{array}{c}6.9950 \\
(9.0343)\end{array}$ & $\begin{array}{c}6.6419 \\
(9.3403)\end{array}$ & $\begin{array}{c}-0.7464 \\
(10.1063)\end{array}$ \\
\hline Corrupt & & & & $\begin{array}{l}-9.4696 \\
(4.8777)\end{array}$ & $\begin{array}{l}-9.5713 \\
(5.4074)\end{array}$ & $\begin{array}{l}-0.9501 \\
(4.8192)\end{array}$ \\
\hline Privo & & & & $\begin{array}{c}4.0920 \\
(6.7583)\end{array}$ & $\begin{array}{c}2.2625 \\
(7.1579)\end{array}$ & $\begin{array}{c}2.1907 \\
(8.1040)\end{array}$ \\
\hline UK Origin & & & & $\begin{array}{l}-26.1155 \\
(7.6851)^{* *}\end{array}$ & $\begin{array}{l}-25.3436 \\
(8.2613) * *\end{array}$ & $\begin{array}{l}-24.6106 \\
(6.8122)^{* *}\end{array}$ \\
\hline Constant & & & & $\begin{array}{r}5.6630 \\
(82.4039)\end{array}$ & $\begin{array}{c}8.6797 \\
(85.2654)\end{array}$ & $\begin{array}{c}90.3302 \\
(92.8927)\end{array}$ \\
\hline Observations & 49 & 48 & 46 & 49 & 48 & 46 \\
\hline R-squared & 0.22 & 0.19 & 0.40 & 0.47 & 0.46 & 0.56 \\
\hline
\end{tabular}

Panel D. Logistic Regressions

Dependent Variable: Catholic Country, which is a dummy variable if the majority of the population in a country adheres to the Catholic denomination. The cultural norms defined by Hofstede (2001) are PDI (the power distance index), IDV (individualism vs. collectivism), MAS (masculinity vs. femininity), UAI (uncertainty avoidance index) and PRA (pragmatic vs. normative). GDP is the average of the PPP adjusted GDP per capita from 1980-2008. Corrupt is the average corruption score from 1996-2000. Privo is the ratio of private credit to GDP averaged from 1999-2003. We employ logistic regressions with robust standard errors. * and ** represent statistical significance at $5 \%$ and $1 \%$ levels, respectively.

\begin{tabular}{|c|c|c|c|c|c|c|}
\hline & (1) & (2) & (3) & (4) & (5) & (6) \\
\hline PDI & $\begin{array}{c}0.0255 \\
(0.0185)\end{array}$ & & & & & $\begin{array}{c}0.0243 \\
(0.0230)\end{array}$ \\
\hline IDV & & $\begin{array}{l}-0.0248 \\
(0.0156)\end{array}$ & & & & $\begin{array}{l}-0.0007 \\
(0.0193)\end{array}$ \\
\hline MAS & & & $\begin{array}{c}0.0135 \\
(0.0129)\end{array}$ & & & $\begin{array}{c}0.0249 \\
(0.0193)\end{array}$ \\
\hline UAI & & & & $\begin{array}{c}0.0426 \\
(0.0167) *\end{array}$ & & $\begin{array}{c}0.0409 \\
(0.0190) *\end{array}$ \\
\hline PRA & & & & & $\begin{array}{l}-0.0273 \\
(0.0143)\end{array}$ & $\begin{array}{l}-0.0327 \\
(0.0182)\end{array}$ \\
\hline$G D P$ & $\begin{array}{c}1.2191 \\
(0.5093)^{*}\end{array}$ & $\begin{array}{l}1.4292 \\
(0.5373)^{* *}\end{array}$ & $\begin{array}{l}1.1123 \\
(0.4976)^{*}\end{array}$ & $\begin{array}{c}0.6199 \\
(0.5415)\end{array}$ & $\begin{array}{c}1.6490 \\
(0.6228)^{* *}\end{array}$ & $\begin{array}{c}1.1258 \\
(0.6447)\end{array}$ \\
\hline Corrupt & $\begin{array}{l}-0.2807 \\
(0.5628)\end{array}$ & $\begin{array}{l}-0.4043 \\
(0.5609)\end{array}$ & $\begin{array}{l}-0.6078 \\
(0.5140)\end{array}$ & $\begin{array}{l}-0.1796 \\
(0.4911)\end{array}$ & $\begin{array}{l}-0.8530 \\
(0.5647)\end{array}$ & $\begin{array}{c}0.2316 \\
(0.6716)\end{array}$ \\
\hline Privo & $\begin{array}{l}-1.5983 \\
(0.8413)\end{array}$ & $\begin{array}{l}-1.5535 \\
(0.8252)\end{array}$ & $\begin{array}{l}-1.3659 \\
(0.7950)\end{array}$ & $\begin{array}{l}-0.9760 \\
(0.7714)\end{array}$ & $\begin{array}{l}-1.2653 \\
(0.7649)\end{array}$ & $\begin{array}{l}-1.4578 \\
(0.8346)\end{array}$ \\
\hline Constant & $\begin{array}{c}-11.9067 \\
(4.7412)^{*}\end{array}$ & $\begin{array}{l}-11.2573 \\
(4.7411)^{*}\end{array}$ & $\begin{array}{c}-10.0349 \\
(4.4189) *\end{array}$ & $\begin{array}{l}-8.2712 \\
(4.7983)\end{array}$ & $\begin{array}{c}-13.1518 \\
(5.5117)^{*}\end{array}$ & $\begin{array}{c}-14.0875 \\
(5.9212)^{*}\end{array}$ \\
\hline Observations & 66 & 66 & 66 & 66 & 61 & 61 \\
\hline R-squared & 0.12 & 0.13 & 0.11 & 0.20 & 0.16 & 0.27 \\
\hline
\end{tabular}




\section{Table XI. Personal Characteristics of the CEO}

If the CEO self reports his interest to be any of the following, then it is considered a risky sport: sky diving, bungee jumping, rock climbing, scuba diving, hang gliding, parachute jumping, hiking, flying, sky surfing, skiing, white water canoeing, football, field hockey/lacrosse, and gambling. If any of the above sports are not reported, but any of the following are reported, then it is considered a non-risky sport: photography, walking, coin collecting, stamp collecting, art, painting, athletics, rowing, bowling, table tennis, tennis, golf, and reading. This classification of sports has been compiled from Berti (2004), Zarevski et al. (1998) and the NIDA database. $*$ and $* *$ represent statistical significance at $5 \%$ and $1 \%$ levels, respectively.

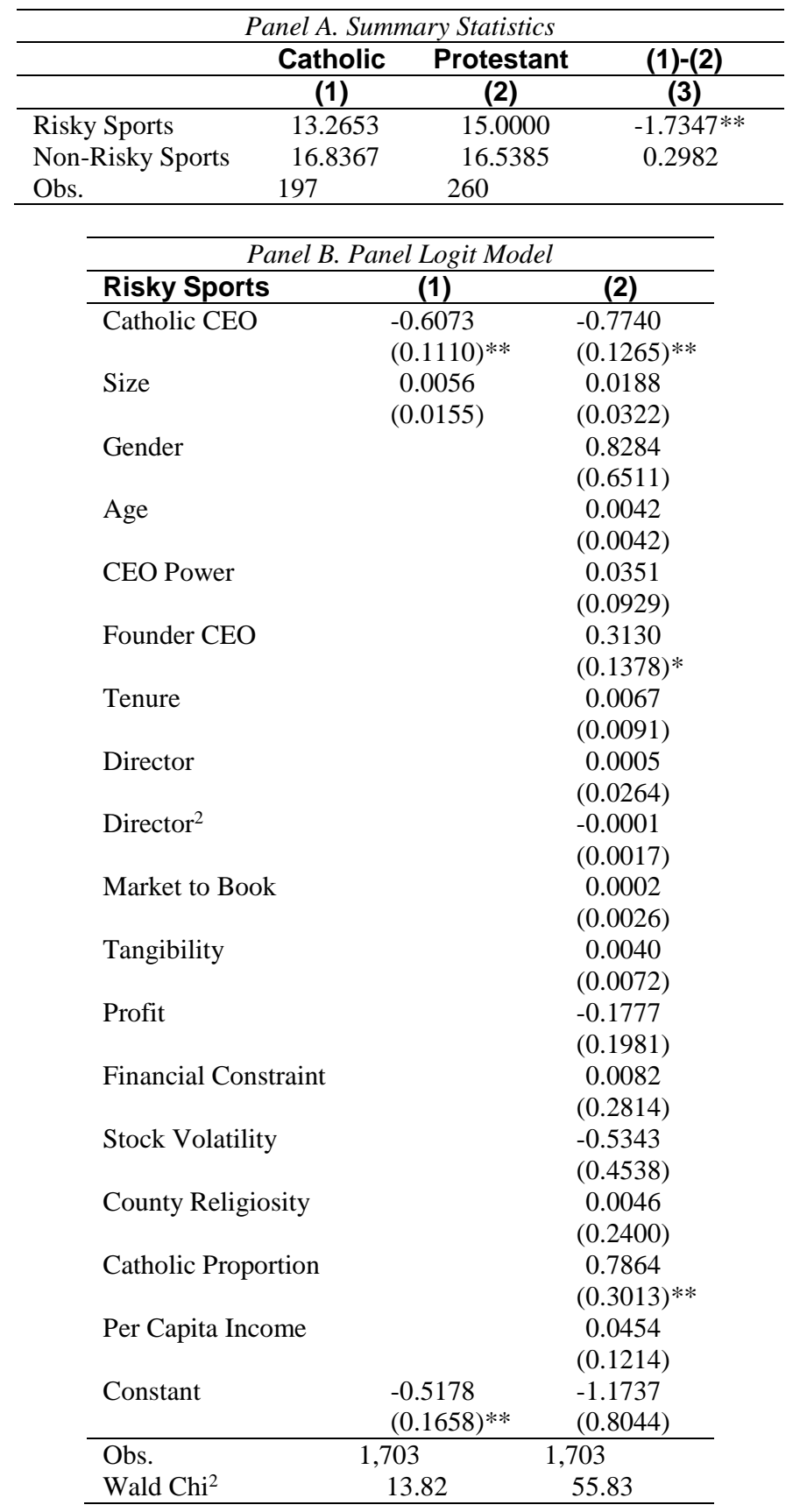




\section{Table XII. Estimates Using Firm Fixed Effects and Inverse Mills Ratio}

Fixed effects panel data regression methodology is used. The variables are as defined previously. Year and firm dummies are used, but not reported. Robust standard errors are reported in parentheses below the coefficients. * and $* *$ represent statistical significance at $5 \%$ and $1 \%$ levels, respectively.

\begin{tabular}{|c|c|c|c|c|}
\hline & $\begin{array}{c}\text { Debt/MVA } \\
(1)\end{array}$ & $\begin{array}{c}\text { Business Segment Total } \\
\text { (2) }\end{array}$ & $\begin{array}{c}\text { Cap Ex. } \\
\text { (3) }\end{array}$ & $\begin{array}{l}\text { Own } \\
(4)\end{array}$ \\
\hline \multirow[t]{2}{*}{ Catholic CEO } & -0.0409 & 0.3301 & -0.0051 & -0.0085 \\
\hline & $(0.0172)^{*}$ & $(0.1428)^{*}$ & $(0.0017)^{* *}$ & $(0.0035)^{*}$ \\
\hline \multirow[t]{2}{*}{ Size } & 0.0351 & 0.1704 & -0.0006 & -0.0048 \\
\hline & $(0.0064)^{* *}$ & $(0.0474)^{* *}$ & $(0.0009)$ & $(0.0012)^{* *}$ \\
\hline \multirow[t]{2}{*}{ Gender } & -0.0094 & 1.1542 & 0.0044 & 0.0031 \\
\hline & $(0.0565)$ & $(0.5543)^{*}$ & $(0.0061)$ & $(0.0073)$ \\
\hline \multirow[t]{2}{*}{ Age } & 0.0023 & 0.0068 & -0.0009 & 0.0005 \\
\hline & $(0.0009)^{*}$ & $(0.0094)$ & $(0.0004)^{*}$ & $(0.0003)$ \\
\hline \multirow[t]{2}{*}{ CEO Power } & 0.0449 & 0.0740 & -0.6687 & 0.0281 \\
\hline & $(0.0514)$ & $(0.0716)$ & $(0.9284)$ & $(0.0140)^{*}$ \\
\hline \multirow[t]{2}{*}{ Tenure } & 0.0016 & 0.0034 & 0.0005 & 0.0013 \\
\hline & $(0.0009)$ & $(0.0101)$ & $(0.0003)$ & $(0.0002)^{* *}$ \\
\hline \multirow[t]{2}{*}{ Director } & 0.0091 & 0.0376 & 0.0015 & 0.0078 \\
\hline & $(0.0075)$ & $(0.1017)$ & $(0.0015)$ & $(0.0037)^{*}$ \\
\hline \multirow[t]{2}{*}{ Director $^{2}$} & -0.0008 & -0.0030 & -0.0001 & -0.0001 \\
\hline & $(0.0008)$ & $(0.0054)$ & $(0.0002)$ & $(0.0003)$ \\
\hline \multirow[t]{2}{*}{ Market-to-Book } & -0.0044 & -0.0795 & 0.0035 & 0.0041 \\
\hline & $(0.0008)^{* *}$ & $(0.0251)^{* *}$ & $(0.0014)^{*}$ & $(0.0010)^{* *}$ \\
\hline \multirow[t]{2}{*}{ Tangibility } & 0.0579 & -0.3334 & 0.1339 & -0.0575 \\
\hline & $(0.0282)^{*}$ & $(0.3017)$ & $(0.0091)^{* *}$ & $(0.0208)^{* *}$ \\
\hline \multirow[t]{2}{*}{ Profit } & -0.4310 & -0.8806 & 0.0504 & -0.0441 \\
\hline & $(0.0571)^{* *}$ & $(0.6650)$ & $(0.0242)^{*}$ & $(0.0517)$ \\
\hline \multirow[t]{2}{*}{ Financial Constraint } & -0.0003 & -0.0139 & -0.0006 & -0.0001 \\
\hline & $(0.0005)$ & $(0.0054)^{*}$ & $(0.0002)^{* *}$ & $(0.0002)$ \\
\hline \multirow{2}{*}{ Stock Volatility } & 0.6879 & -5.2237 & 0.0734 & 0.0566 \\
\hline & $(0.0742)^{* *}$ & $(1.2025)^{* *}$ & $(0.0273)^{* *}$ & $(0.0562)$ \\
\hline \multirow[t]{2}{*}{ Industry Debt/MVA } & 0.2101 & & & \\
\hline & $(0.0780)^{* *}$ & & & \\
\hline \multirow[t]{2}{*}{ Inverse Mills } & -0.4975 & 0.2269 & -0.2260 & -0.3082 \\
\hline & $(0.1396)^{* *}$ & $(0.0445)^{* *}$ & $(0.0426)^{* *}$ & $(0.1099)^{* *}$ \\
\hline \multirow[t]{2}{*}{ Constant } & 0.2169 & -4.3679 & 0.4079 & 0.5005 \\
\hline & $(0.2289)$ & $(1.7379) *$ & $(0.0655)^{* *}$ & $(0.1581)^{* *}$ \\
\hline Adj. $\mathrm{R}^{2}$ & 0.74 & 0.72 & 0.49 & 0.25 \\
\hline
\end{tabular}

